Portland State University

PDXScholar

\title{
Consumer Acceptance of Eco-Innovations in the Athletic \& Outdoor Industry
}

\author{
Ethan Cotton \\ Portland State University
}

Follow this and additional works at: https://pdxscholar.library.pdx.edu/honorstheses

\section{Let us know how access to this document benefits you.}

\section{Recommended Citation}

Cotton, Ethan, "Consumer Acceptance of Eco-Innovations in the Athletic \& Outdoor Industry" (2018). University Honors Theses. Paper 592.

https://doi.org/10.15760/honors.601

This Thesis is brought to you for free and open access. It has been accepted for inclusion in University Honors Theses by an authorized administrator of PDXScholar. Please contact us if we can make this document more accessible: pdxscholar@pdx.edu. 


\section{CONSUMER ACCEPTANCE OF ECO- INNOVATIONS IN THE ATHLETIC \& OUTDOOR INDUSTRY}

Senior Thesis // Spring 2018

\section{Ethan Cotton}

Portland State University | School of Business| Mentor: Jacob Suher Ph.D. 


\section{ABSTRACT}

In an age of increasing consumer awareness and connectedness, demand for company level innovation that reduces harmful environmental effects has morphed into a baseline expectation. However, an attitude behavior gap is present between consumers' stated preferences for sustainably innovation in the products they purchase and their follow through purchase behavior. Research presents conflicting evidence concerning the primary motivation for purchasing with the environment in mind, is it concern for the planet, are consumers just following the way of the crowd, or do they not even care at all? Companies often fail to address the sustainable attributes of products due, in part, to the liability that accompanies mentioning attributes focused on sustainability innovations. While eco-innovations have become far more common in all industries, the athletic and outdoor industry has consumers whom are particularly connected to the environment and companies still struggle to tell sustainability stories. This research contributes findings to consumers' preferences for specific attributes of sustainability, between material, supply chain, and ethical innovations. A qualitative industry survey established baselines for these innovations which were tested in two iterations of consumer facing surveys $(n=23,103)$. Emergent findings presented consumer preference for ethical innovation over innovation in material or supply chain and conflicting preference for material durability and material environmental friendliness and conflicting preference between material and supply chain environmental friendliness which may be moderated by product function or measured by physical proximity. These emergent findings are being tested in a national sample $(n=200)$ with intent to contribute to academic and industry knowledge about consumer preferences of different aspects of sustainability innovations. 


\section{BACKGROUND \& INTRO}

Consumers around the world have become increasingly accustomed to having instant access to goods and services they desire, but it has come at a cost. Humanity's current consumption rates have left irreplaceable damage on the environment as consumer household purchases have accounted for an astonishing $40 \%$ of the environmental damage (Joshi \& Rahman, 2015). While awareness of this epidemic is growing, especially among younger generations, i.e. Millennials, of whom $92 \%$ are more likely to purchase from companies they deem ethical and 55\% will pay extra for products and services from companies committed to social and environmental impact (Retail Sustainability in an Omni-Channel World, 2015). If the rate at which consumers in the United States consume was translated globally, we would need five Earths to sustain these insatiable purchasing patterns (Sheth et al., 2011). As resource scarcity has become a more prevalent issue due to the damaging effects of consumption, sustainable consumption and production is a trend that is here to stay (Geng et al., 2017).

There is growing consumer awareness of social stakeholders and maintaining the environment around us, so businesses have also recognized the need to innovate and maintain their organizational reputation, legitimacy and performance (Varadarajan, 2017). Nearly every large player in any industry has sustainability initiatives but their response and transparency to consumers varies. Bolte (2017) revealed that although the prominent Nike brand has identified the growing trend of consumers caring about corporate ethicality, interestingly, the marketing team remains hesitant to market specific sustainable attributes. If the product does not perform as advertised, a brand like Nike could be subject to claims of greenwashing if their innovations did not hold up. Simply put, the risk is not worth the reward despite the clearly growing global trend. Eco-innovation, defined by the EU as "innovation resulting in significant progress towards the 
goal of sustainable development, by reducing the impacts of our production modes on the environment, enhancing nature's resilience to environmental pressures, or achieving a more efficient and responsible use of natural resources" (Eco-Innovation the Key to Europe's Future Competitiveness, p. 2) has become a more accepted term to describe sustainable innovations/ development. Executives at major brands, such as Adidas, interpret the reduction of their environmental and carbon footprint as a financial measure to report to shareholders (LiedtkeNYT Sustainable Luxury Video, 2016).

Although businesses have started to own up to their responsibilities, there is an overall lack of focus on the consumer in this emerging point of focus for businesses (Johsi and Rahman, 2015; Ki and Kim, 2016; Lunbland and Davies, 2016; Ramirez, 2013). According to Sheth et al. (2011), failing to consider the consumer as a valuable stakeholder for sustainability efforts will drastically decrease efficiency of sustainable business endeavors. Corporate Social Responsibility (CSR) is a common term in company culture that can encompass a broad array of initiatives including: establishing and living by strong brand values producing certified organic/fair trade, partnering with charity, reducing packaging waste, advancing supply chain allocation processes to minimize product movement, implementing product recycling initiatives and investing in alternative energy (Retail Sustainability in an Omni-Channel World, 2016). While this is an impressive array of means for a business to be working toward a bigger goal than dollars, do the different aspects of CSR to add or degrade consumers' preference for products? This research is focusing on specific innovations, encompassed by CSR, specifically those of product versus supply chain to measure how these specific attributes affect consumer purchase preference. The research question is: what implications do attributes of product versus 
place (supply chain) have on consumer purchase preference for eco-innovations in the athletic and outdoor industry?

The current academic research presents conflicting conclusions about the drivers and barriers for consumer preference of sustainable eco-innovations. Joshi and Rahman (2015) list a number of factors like high environmental concern and overall preference for green attributes as reasons for purchase. But Lundblad and Davies (2016) argue consumers may be meeting intrinsic needs to feel better about themselves and Geng (2017) agrees with Sheth (2011) that the benefits of these innovations cannot be realized until consumers understand what they are and how they affect them.

Emergent findings presented consumer preference for ethical innovation over innovation in material or supply chain. Einwiller (2010) established a finding that consumers' reliance on media allows a limited understanding of company behavior that can focus on social impacts and although this emphasizes media relations to connect with consumers this provides initial context to why consumers may focus on social aspects of innovation, as these get portrayed most often in media (p. 312). Conflicting preference of material durability vs. material environmental friendliness emerged within this research as these two material innovations were preferred equally in a direct comparison. However, these attributes had conflicting preference when compared to other innovations in the study. Further conflicting preference was demonstrated between material and supply chain environmental friendliness, with the only difference being the location of innovation. Supply chain environmental friendliness was significantly preferred. This confluence in preference is being investigated by moderating product function, between utilitarian and hedonic (performance or fashion), or measured by the consumer's physical 
proximity to the innovation. These emergent findings were the result of two iterations of consumer surveys and are being tested in a national survey.

\section{LITERATURE REVIEW}

According to Peloza \& Shang (2010), understanding the consumer facing implications that attributes of product versus place have on consumer preferences is necessary to advance corporate social responsibility but this task is both difficult and not all encompassing. Motives behind a consumers' desire to consume in a more sustainable manner may be due to high concern for the environment and the functional attributes of the green product (Joshi \& Rahman, 2015). However, Lundblad \& Davies (2016) argue egoistic values, such as a sense of accomplishment toward a bigger goal and self-esteem, play a larger role than responsibility, protecting the planet and social justice; combined. Businesses need to innovate their marketing practices to retrofit storytelling techniques that provide education and awareness to consumers about CSR initiatives and the value they can add to the consumer (Del Pilar, 2017; Geng et al., 2017).

Otherwise, with such little knowledge of the current consumer mindset orientation toward these initiatives, sustainability initiatives could be ineffective, or perhaps ironically, decrease preference of sustainable products (Luchs et al., 2010). Luchs et al. (2010) continues to highlight the illegitimacy of simply marketing green product attributes because, instead of pushing a consumer to want to buy a more sustainable product, it can degrade purchase intention. Lin and Chang (2012) echo Luchs et al.'s findings by examining the use of greener soap alternatives with the discovery that the potential positive impacts of the increased environmental friendliness of these products may be offset, because consumers associate green with less effective, and in turn, use far more product than they would otherwise. These findings lead to a conclusion that 
consumers' perceptions that sustainable products are less strong than less eco-friendly ones, ethicality may not be enough to overcome stereotypical high prices of green product, but this can be overcome with explicit product information where the durable attributes of the products are highlighted in tandem (Luchs et al., 2010, Egbue and Long, 2010, Lin and Chang, 2012). For example, Patagonia Inc. successfully demonstrates how products can be communicated to overcome these consumer preconceptions with their Workwear line. Workwear is inherently understood as something tough to be utilized on the job, but Patagonia is sure to mention, "The industrial hemp fiber gives the canvass toughness and durability; the recycled polyester and organic cotton allow a soft hand and allow a tighter weave," (Workwear).

A United Nations Environment Program (2005), suggests that while 40\% of consumers' report willingness to pay for "green products," a mere $4 \%$ of them followed through with a purchase. This tenfold decrease between the stated preference and buying behavior reveals the impact of the sustainability liability as consumers in this study clearly did not perceive enough impact to modify behavior. Even though younger generations such as Gen-Z have been identified as willing to pay more for green products as opposed to conventional ones, with willingness to pay up from 55\% in 2014 to $72 \%$ in 2015 (Green Generation: Millennials Say Sustainability Is a Shopping Priority), there is a serious and measurable gap between how consumers feel and their purchasing patterns (Sheth et al., 2011).

Mitigating consumers' preconceptions about a negative correlation between sustainability and strength (Luchs et al., 2010, Lin and Chang, 2012) may be a good starting point however, industry expert Del Pilar (2017) brings up the idea of challenging this way of thinking through effective education embedded in marketing storytelling. Geng et al. (2016), studies how to motivate more sustainable consumption (in developing countries) and reveals findings that 
education to improve awareness and understanding of eco-innovations will provide win-win opportunities for consumers and businesses alike. Mindful Consumption (MC) principles reveal how encouraging $\mathrm{MC}$ is better for business than overconsumption. When marketers neglect categories or products, under consumption usually occurs while over marketing means demand is higher than supply and consumers need to wait for product and marketing dollars have been essentially wasted. However, optimal marketing will fulfill customer needs without wasting marketing dollars without promoting over consumption (Sheth et al., 2011). Through this literature review, a gap seems to be opening up. The consumer's responses and preferences to various aspects of sustainability vary so, the question remains, what do they want?

While it is important to understand how companies can better deliver value to consumers, other industries are tackling similar sustainability issues while keeping the consumer in focus. By observing what has been done, successful or not, discretion to gauge future research and its potential outside impact can start to be formed. Table 1 in the Appendix provides a full literature review of current research and is broken down to reveal general and consumer findings. Research attempting to identify and overcome barriers to food packaging recycling have been undertaken which provided a mixed bag of results. Consistent with the attitude versus mindset confluence outlined earlier (Sheth et al., 2011), information treatments did not significantly affect consumer recycling behavior, but altered preferences for packaging materials (Klaiman et al., 2016). Further cross industry research corroborates these ideas via Egbue and Long (2012) in their study on the consumer acceptance of electric vehicles. This article reveals that although sustainability and environmental benefits of electric vehicles are important factors for consumers, they do not come before cost and performance of the vehicle (Egbue and Long, 2012, p. 724). Complimentary to Lin and Chang (2012) and Luchs et al. (2010) conclusions on 
perceptions, the consumers may not be convinced that the green option of electric vehicles is more effective than their less eco-friendly options (Egbue and Long, 2012). While the best method to educate consumers about the power of eco-innovation is unknown (Geng et al. 2016), it is vitally important to our planet, regardless of industry, to catalyze a shift to help "make sustainability cool" and using effective story telling may be the most organic method (Del Pilar, 2017).

\section{ATHLETIC \& OUTDOOR INDUSTRY FOCUS}

Given the amount of research suggesting a need to better understand the consumer behavior in response to various aspects of sustainability, that will be the focus of the research for this thesis. There is an important distinction to be made about the industry of focus for this research and the reasoning behind it. The athletic and outdoor (A\&O) industry will be the primary focus for this study for a number of reasons. A large contributing factor to focus on this study is the close location and access to industry that the researchers have while being based in Portland, Oregon. The three largest athletic footwear and apparel companies in the United States have headquarters within a ten-mile radius and these professionals have immense insight into the consumers that articles simply cannot provide. Bolte (2017) and Del Pilar (2017) are both industry experts and Moore (2017) is another confirmatory information source from the industry to reaffirm the validity of the lack of emphasis on consumer focus for sustainable consumption research. She realizes the drastic importance consumers provide and continued to elaborate on the confluence of demand and follow through purchasing patterns of customers who claim to want sustainable product.

Further, brands in the A\&O industry have a unique connection to the world around us as they provide products and services to allow consumers to enjoy their environment to its full 
potential. These emotionally intensive activities mean brands are well connected with their consumers and competitors and have been united around organizations like the Outdoor Industry Association addressing sustainability related challenged through cooperation for many years (Gilbride, 2014). This immense market generates $\$ 887$ billion in consumer spending annually, sustains 7.6 million American jobs and generates $\$ 65.3$ billion in federal tax revenue and $\$ 59.2$ billion in state and local tax revenue every year (OIA Releases the Outdoor Recreation Economy Report, 2017). Consumers outside this industry will still be included in the study as those in this industry are willing to pay more for durability, quality, and comfort (OIA ConsumerVue Executive Summary, 2014, p. 4) which could lead to potential bias and less generalizability. In addition, little research has focused exclusively on this industry. Hasford and Farmer (2017) provided insight into a specific product within this industry and the green initiatives behind it but revealed the contrasting inferences the consumer makes after learning about the eco-innovation when compared to completion (p. 1238).

Currently, there are several brands working to promote their eco-innovations in product and supply chain. Some examples include Columbia Sportswear and the Adidas Group. Columbia Sportswear, headquartered in Portland, OR, markets one of their products, the OutDry Eco Jacket as, "the ultimate sustainable waterproof-breathable jacket for harsh conditions" (OutDry Extreme Eco Landing). It is made with 100\% recycled fabric from 21 plastic water bottles, has no intentional PFC use as well as using no dyes to save water ("Columbia OutDry Extreme Eco", 2017). Columbia has marketed this product by highlighting the waterproofing as a key feature that is highly effective along with being sustainable and they secured a celebrity to endorse the product to provide humility and relatability to help educate consumers during a marketing campaign. On the supply chain side, Adidas has been making supply chain 
innovations with their new "Speedfactories". Only two were being tested, one in Germany and another in Atlanta, GA, and these factories utilize new 3D printing technology to make product quickly in real time response to consumer demand. This factory will not only optimize transportation logistics by limiting long distance shipping, but allow for more local sourcing and production to eliminate the societal degradation issues associated with producing in developing countries across the globe ("Adidas Will Open Atlanta-Based Facility to Make Shoes in America", 2016). More eco-innovations in the industry can be seen in Table 2.

\section{PROPOSED RESEARCH}

This study will utilize qualitative and quantitative research methods: in-depth interviews, consumer surveys, and choice experiments. In-depth interviews were used to identify the most important eco-innovation characteristics that can be analyzed in further detail through survey. Purchase intention and willingness to pay are very difficult metrics to obtain and measure however they are indicative of how a consumer truly values the attribute in question. Utilizing a survey will provide insight into what consumers consider to be most valuable in the realm of eco-innovation and provide discourse to answer why these values are important through future research. Not only will this research shed light on what attributes of eco-innovation consumers find valuable, it will contribute ideas of how to market more efficiently to these consumers, possibly to challenge their way of thinking and initiate a shift toward more mindful consumption practices. Although Hasford and Farmer (2017) provided insight into how CSR impacted consumers' consumption preferences against competitors in the industry, pitting the product against a competitor is not the idea behind this research.

While brand affiliation and product differences will be important to consider, understanding the mechanisms driving consumption preference between types of innovation, not 
necessarily the brand behind them, is where this research will shine a spotlight. This will begin with descriptive qualitative research to help set baseline understandings of consumer preferences, utilizing a survey and in person interviews. After reviewing the literature surrounding this topic, see Table 1, there is a gap in understanding that needs to be addressed: if the consumer cares as much as some of these articles seem to state, what do they care about most, if at all? While the previous research has examined consumers' attitudes, drivers and barriers toward ecoinnovation, understanding if they react more strongly toward innovations in product or supply chain in the Athletic and Outdoor Industry will aid in helping understand if this industry has the potential to catalyze a shift toward more sustainable consumption. Telling the right stories, that are known to be backed by consumer relevance, through marketing could help consumers continue to realize their impact and inspire change across the globe.

\section{METHODS AND ANALYSIS}

\section{Overview of Primary Research}

Following the literature review and proposed research, a funding application to support primary research was submitted to PSU's Institute of Sustainable Solutions (ISS). With great delight, the application was accepted and the scope of the research was able to be increased. With that, the testing for this research followed a protocol that was designed to be easily replicable, helped derive new sources of information, checked against potential biases and ensure the results answer a relevant research question, for academia and the industry alike.

Consumer behavior has been studied surrounding sustainability and the literature presents evidence of conflicting mindsets, which provides an opportunity for research understanding attitudes about varying attribute specific eco-innovations. The initial inception of this research topic was aided greatly by industry professionals and their input, which was documented and 
utilized as the first primary research in the study. A survey for professionals who had any knowledge of sustainability at their respective companies was designed as an emergent research method to contribute attributes of eco-innovations this research can focus on.

Once qualitative data was captured and assessed from the industry, an initial consumer facing pilot survey was developed. This survey identified and categorized different innovations from the industry and questioned participants if they preferred an innovation through a choice test to provide some exploratory and descriptive data $(\mathrm{n}=23)$. Other behavioral and demographic variables were collected and analyzed with the choice data. Once the major findings were assessed, a larger consumer survey was developed. The sample methodology was similar to the first test, except this survey started to compare the innovations against each other, rather than a null innovation option. Further, respondents were able to give slightly more detailed information about their overall ranking and perception of the innovation through questions on their willingness to pay and how much each innovation discussed should "cost" (n=103). Upon completion and analysis of results of the second survey, the final survey was developed. Due to time constraints, the data collection for the national sample will be discussed in a future paper, this research will present and discuss the emergent research questions that came from analysis. A description of each section will follow below.

\section{$\underline{\text { Industry Interviews }}$}

This research topic was inspired thanks to the Athletic/Outdoor Industry Certificate at PSU's School of Business where professionals from Nike, Adidas, Columbia and other companies in the Athletic and Outdoor industry come to teach classes and immerse students in the A\&O industry. Not only were connections with professionals, teachers, and guest speakers in the industry developed, since the location of this university is so physically close to major 
company headquarters, the opportunity to gain access to valuable industry insight was unmatched. Given the proximity and strong network of investigators, industry opinion has been considered and valued from the inception of the research. Outside of the personal preference and industry interest, Gilbride (2014) also points out that consumers within this industry are particularly connected to the planet because purchases can help enhance life outside. As these consumers may be more aware and appreciative of their surroundings, their behaviors may shift behaviors more swiftly than those without this kind of connection.

The conversations with industry revolved around measuring sustainability at a company level and what consumers thought, to help guide thinking to ensure that the project was on the right track. The interview process saw a few up front limitations which could have added to the overall robustness, but the value adds of industry specific information that was obtained was incredible. Early discussions were not standardized, they simply explored the topic to assess relevance in the industry environment. It would have been beneficial to develop a standardized interview approach earlier in the process. Eventually, the interviews did go through a survey but acquiring the data itself was a challenge. Incentivizing participation was mostly based on goodwill from industry interest in the subject, but navigating busy professional schedules proved to be a massive barrier. It would have been amazing to double, or even quadruple the amount of industry respondents ( $\mathrm{n}=5)$ but, bad timing and scheduling barriers were eventually overlooked given the scope of the study. Bridging the gap between the theory that is applied in academia and the current status of the industry was a rewarding process which helped develop a strong platform for consumer facing choice tests to start investigating preference.

The survey asked three fundamental questions to help bolster and deepen the general understanding of the industry's attitudes and implementation of eco-innovations. Please 
reference the Survey Appendix for the full line of questions, Industry Recruitment Protocol, and Industry Consent Form.

1. Has your company publicly shared any aspects of sustainability innovation with its customers? If so, what types of sustainability innovations are incorporated into currently available products or have been publicly disclosed?

2. What aspects of sustainability innovation in the athletic and outdoor industry do you expect other companies to offer in the future?

3. What aspects of sustainability innovation in the athletic and outdoor industry do you believe are most important to consumers?

Further, this survey was successful in its intended purpose of finding major themes within the innovations that industry professionals addressed. The first question was designed to expand the knowledge of innovations in the industry. Before this industry facing survey, research was done on large companies like Nike and Columbia Sportswear who actively publish Corporate Social Responsibility (CSR) Reports on their work with sustainable innovation. While these provide a lot of transparency they are meticulously detailed and some had not seen updates in almost two years. The first question gave a high level overview, instead of the in-depth level of information present in CSR reports, to help expand understanding. To open the scope outside the respondents' company, the second question asked about the expectation of other company's innovations to expand responses from what a professional might be doing internally in their organization to their perception of the market as a whole. The final question brought up the consumer because that is the end focus of this research: what does the consumer think?

Ultimately, this question was to pose a way to gauge anything that seems extra important. This was a first general evaluation of how consumers are responding to the current status of the 
industry and yielded rich responses.

\section{$\underline{\text { Results }}$}

This survey allowed innovations currently being offered to consumers from companies to emerge. Comments mentioning a consumer desire for "transparency" and the need for "trust, knowledge, and general understanding" were common along with mentions of many methods of recycling, either in use of end material or in the manufacturing stage. But one respondent was sure to mention the barrier of price. Value is driven by how much benefit you can get for a certain price; and that is a significant barrier to acknowledge. This study will not utilize price as a variable as the attitude of consumer unwillingness to spend for sustainability due to weakness associated attributes has been described (Sheth et al., 2010, Luchs et al., 2010, Lin and Chang, 2012). Overall interpretations of the comments from the survey indicated there were many considerations to make for selecting the different innovations to put in the survey and that there was a good amount of industry relevance where professionals believe more information about consumers' preferences would be helpful to their organizations and the consumers themselves. See below for the list of innovations coded from this survey's results.

While some of the innovations are very specific and others are quite general this table speaks to the initial difficulty in standardizing which innovations were the most important to focus on and how to categorize them for comparison by consumers. The analysis of these surveys was done by one investigator through coding, which is another limitation of the study. It would have been better to have at least one alternative coder to look for differences. However, given the low sample size, the information was still considered in tandem with academic research but could reduce any preconceived biases in the future. The industry survey played a very direct role in influencing the pilot consumer study. The implications of the industry survey 
on the pilot test were on the choice of innovations for comparison, which will be discussed in the next section.

\section{Overarching Consumer Survey Logic}

The iterations of consumer surveys in this research followed a similar structure. Each survey had a consent form and instructions to read each question carefully. The first section of every survey was an "Innovation Choice Comparison." In these sections, images and base descriptions of products were provided. The respondent then had the option of choosing the base product, described as having "no changes to materials or production practices" or a version of the product with an innovation description attached. The versions with innovation descriptions could be compared against each other as well. The subsequent section asked the respondents to perform "Attribute Ranking" of the eco-innovations that were being tested. This involved scoring innovations on a scale based on preference during purchase/perceived environmental impact or indicating willingness to pay as a percent of cost of the overall product. Following ranking, respondents were asked questions about their "Behavior/Usage." These questions asked about their actual purchase history in the industry, frequency of purchase, appreciation of products, and intended functionality of the products shown. "Psychographics" includes an environmental sensitivity scale to gauge consumers' preferences on sustainability and overall environmental friendliness. Finally, respondents were asked basic "Demographic" questions to further be able to filter the data. Three surveys will be discussed, each of them follow the same logic and flow, and the differences and development of the surveys will be discussed below.

\section{Pilot Survey}

This consumer choice survey was effective in uncovering the most relevant innovations 
from the industry survey and utilizing those to inform innovation descriptions. These innovation descriptions accompanied a product description to set up an initial A/B choice test on what innovations consumers prefer most, if there is preference for innovation at all. A full overview of the survey in full detail in available in the Survey Appendix. Determining the most relevant innovations involved cross referencing other sources; a discussion of why each innovation was chosen for this test can be found in the Appendix (Survey 1 Innovation Discussion). This discussion provides insight into real world industry examples of the innovations presented in the survey and references to the literature to provide further justification. See the table below for the innovations chosen and the mean for the respondent's attribute importance score which is on a scale from one to seven. One indicated the attribute was not important, a four in the middle of the scale indicated somewhat important, and a seven indicated the attribute was very important.

Pilot Survey Innovation List \& Attribute Rank (1-7 scale)

\begin{tabular}{|c|c|c|c|}
\hline \multirow[t]{5}{*}{$\begin{array}{l}\text { Material } \\
\text { Innovations }\end{array}$} & $\begin{array}{l}\text { 1. Materials devoid of wasteful or harmful } \\
\text { chemicals }\end{array}$ & 6.409 & \multirow[t]{5}{*}{$\begin{array}{l}\text { Mean= } \\
5.609\end{array}$} \\
\hline & $\begin{array}{l}\text { 2. Materials that can be traced to ensure ethical } \\
\text { sourcing }\end{array}$ & 5.682 & \\
\hline & 3. Less materials, leaving behind less waste & 5.409 & \\
\hline & 4. Materials that have been repurposed or recycled & 5.318 & \\
\hline & $\begin{array}{l}\text { 5. Durable materials that are designed to last a } \\
\text { long time }\end{array}$ & 5.227 & \\
\hline \multirow{5}{*}{$\begin{array}{l}\text { Supply } \\
\text { Chain } \\
\text { Innovations }\end{array}$} & $\begin{array}{l}\text { 1. Manufacturing in a factory with ethical social } \\
\text { standards }\end{array}$ & 5.818 & \multirow{5}{*}{$\begin{array}{l}\text { Mean } \\
(4)^{*}= \\
5.034 \\
* \text { doesn't } \\
\text { include } \\
\text { SC } \\
\text { innovation } \\
5\end{array}$} \\
\hline & 2. Less and/or recycled packaging materials & 5.227 & \\
\hline & $\begin{array}{l}\text { 3. Delivery process to reduce environmental } \\
\text { impact }\end{array}$ & 5.227 & \\
\hline & 4. Manufacturing close to location of customer & 3.864 & \\
\hline & $\begin{array}{l}\text { 5. production utilizing clean energy and without } \\
\text { toxins "manufacturing with clean energy" }\end{array}$ & N/A & \\
\hline
\end{tabular}

For this pilot quantitative survey, a "fashion" (hedonic), "neutral," and "performance" (utilitarian) version of a jacket and shoe were shown to all respondents for comparison against a 
similar version with no innovations or changes. Not only did this allow insight into any differences between the type of product and the preference for innovation, but it also allowed exploration of innovation preferences, based on the products intended usage. The Appendix has a graphic (Survey 1 Innovation Choice) to help reveal the most preferred innovation in the choice tests was "Supply 3" (production utilizing clean energy and without toxins) and the least preferred innovation was "Supply 2" (manufacturing close to location of consumer). A typo resulted in "Supply 3" not being included in the attribute ranking section of survey 1 . While both the most and least preferred innovations are on the supply chain side, the product innovations were picked higher on average (Choice $=.913)$ than average in the supply chain category $($ Choice $=.868)$. These choice scores and following data are on a scale of zero to one. Zero indicates preference for no innovation and one represents preference for the innovation. The data analysis from this survey was insightful in answering some preliminary questions and provided a base for analysis practice. This survey checked whether consumers cared at all about innovation. This was an important benchmark because if results indicated there was no preference toward innovation in general, the validity of the study would have greatly decreased because it would explore attitudes of something that consumers don't want in the first place. However, the results from this survey indicated that out of the 23 respondents who took the survey, 22 chose more products with innovations than those without. The mean overall choice for innovations vs products without innovations was .891 , indicating a strong preference toward innovations rather than base products. This finding, although simple, was a huge takeaway for ensuring validity and could likely be pursued as a research question of its own. Survey 1 Respondents Choice in the Appendix provides a visual of the spread of the respondents' choices. 
Another simple insight was the lack of difference in choice between product type and function. The Survey 1 Product Choice graphic shows each participants choices for each product category in the survey. The products are categorized by letter where A is athletic, B is neutral, and C is fashion. Shoe B (neutral) had the lowest preference with a mean choice score of .8522 , while Jacket A (athletic) \& Shoe C (fashion) had the highest with identical mean choice scores of .9310. This minimal lack of difference is significant for the research and the Appendix shows Survey 1 Product Standard Deviation to show the average standard deviation for Shoe B (.3557) is very close to the standard deviation of the total choices (.3123). When comparing overall choice between all jackets and shoes, the mean of preference for both product categories is .89 , further bolstering the argument the lack of difference observed was significant to consider.

Although there is some amount of variance between these choices and the sample size in this study ( $\mathrm{n}=23$ ) could have been larger and more diverse than a classroom pool, the lack of major difference was a positive indicator. Comments on the survey indicated redundancy needed to be reduced and this survey tested preference through sixty choice questions (three product types, two products, and ten total innovations for each). This repetition may have been a limitation in this survey method, however, while it was cumbersome for users complete this section of the study, understanding there was not a lot of significant difference within the data was especially valuable. Further, this survey used images of products and descriptions that were found online. Nike was chosen as the brand because of its recognition and likely familiarity and was kept consistent throughout the choice section. Although Nike is familiar this could have affected responses in a positive or negative manner. After the choice section of the survey, respondents were probed about usage of products.

A question this survey hoped to answer was do respondents prefer any innovation at all? 
While the sample size was limited and the demographic of respondents were likely very similar, the generalized strong preference for innovations provided justification to move forward with the experiment. The results from the pilot pointed toward the majority of respondents attaining some understanding of the survey and pointing to results that innovation is preferred and some innovations are preferred more than others. Discovering which innovation were preferred against others was the way the second survey was developed.

With five innovations in "material" and five innovations in "supply chain" that all needed to be tested amongst three versions of two different products, the repetitiveness and volume of questions added up quickly. Future surveys needed to have less choice comparisons that were more meaningful. The learning from the first test revealed that the survey was on the right track and opened up the opportunity to start diving deeper into the differences between the innovations themselves. Moving forward the product function will not be considered as it adds considerable volume to the choice test and it did not reveal meaningful differences. Reducing the volume of questions while maintaining integrity of the testing protocol was considered moving forward. This survey provided simple insight that innovation is preferred. Given this, comparing between innovation types was the next step to take to start examining how the innovations interact with each other to force a tradeoff for respondents.

\section{PSU Survey}

The second consumer survey followed the logic from the first survey and the Survey Reference Appendix (PSU Survey Questions) has a full overview of all questions asked. Updates to the design of the pilot survey included the number of innovations that participants were asked about, which was reduced from ten to five. This helped usability and generalizing some of the specific innovations Grouping multiple innovations together or simplifying the idea allowed for 
this shorter and user friendly list of innovations that the PSU Survey utilized:

- Material 1 (M1): Increase use of environmentally friendly materials

- Material 2 (M2): Increase use of durable and long-lasting materials

- Supply Chain 1 (SC1): Reduced use of resources to manufacture, package, and deliver the product.

- Supply Chain 2 (SC2): Increased use of environmentally friendly practices to manufacture, package, and deliver the product

- Demand 1 (D1): Ethical practices throughout all materials and production practices

The number of functionally specific products those innovations were shown in was also reduced from six to two in this survey. Further, the preference section of the survey was expanded as it not only asked the respondent to rank the innovations on a scale of one to seven, but also utilized a sliding scale, from negative one-hundred to one-hundred, for the percentage of how much more or less respondents would be willing to pay if the innovation of question was in a product they were about to purchase. The survey also asked how much the respondent thought the company should pay as a portion of the total cost of the product for each specific innovation being tested. The usage section was also bolstered. Instead of just asking respondents if they would purchase a product based on innovation, the question of if they bought any athletic/outdoor product at all was asked, followed by if they used it, ending with if they had bought any product to reduce environmental impact. Some of the questions were adapted from Gomez's (General Attitude and Behavior Survey Baseline Findings, 2007) study on the environmental issues that concern California consumers found the most. These behavioral questions asked about overall awareness of recycling and if the respondent was aware of any action they took to help reduce impact. The demographics asked about age and location as extra 
checks for finding differences in the data. Descriptions of the questions and the data outputs can be seen in the Appendix (Survey 2 Question \& Data Descriptions).

The testing protocol in the second survey also changed slightly compared to the first. Not only were the innovations compared against a version of a product with no innovation, but they were also tested against each of the other four innovations. See below:

\begin{tabular}{|l|l|l|l|}
\hline \multirow{3}{*}{$\begin{array}{l}\text { Innovation } \\
\text { vs. }\end{array}$} & Material 1 & vs. & Material 2 \\
\cline { 2 - 4 } & Supply Chain 1 & vs. & Supply Chain 2 \\
\cline { 2 - 4 } & Material 1 & vs. & Supply Chain 1 \\
\cline { 2 - 4 } & Material 1 & vs. & Supply Chain 2 \\
\cline { 2 - 4 } & Material 2 & vs. & Supply Chain 1 \\
\cline { 2 - 4 } & Material 2 & vs. & Supply Chain 2 \\
\cline { 2 - 4 } & Material 1 & vs. & Demand 1 \\
\cline { 2 - 4 } & Material 2 & vs. & Demand 1 \\
\cline { 2 - 4 } & Supply Chain 2 & vs. & Demand 1 \\
\cline { 2 - 4 } & Supply Chain 2 & vs. & Demand 1 \\
\hline \multirow{4}{*}{$\begin{array}{l}\text { Innovation } \\
\text { vs. }\end{array}$} & Material 1 & vs. & Material 0 \\
\cline { 2 - 4 } Innovation & Material 2 & vs. & Material 0 \\
\cline { 2 - 4 } & Supply Chain 1 & vs. & Supply Chain 0 \\
\cline { 2 - 4 } & Supply Chain 2 & vs. & Supply Chain 0 \\
\cline { 2 - 4 } & Demand 1 & vs. & Demand 0 \\
\hline
\end{tabular}

\section{$\underline{\text { Results }}$}

The choice data had some interesting overall trends. Initially, the same checks that the first survey had were also performed on the second for continuity and especially considering the smaller sample size of Survey 1. The graphic, PSU Survey Brand/Product, shows the numbers for the second survey, based on product and brand. There did not appear to be any meaningful differences between the products as they saw means of choices, standard deviation and variance. Please see table PSU Survey Similarity. There average of choice, on a scale of zero to one, was 0.349 for jackets and 0.367 for shoes in this test which demonstrates, consistent with the pilot survey, that the type of product is not having for influence on respondent's choices. This survey did introduce a new variable described as brand. Eighty-four (81.55\%) respondents took this 
survey with the same images used in the first version, however a brand agnostic version was developed and introduced for the final $19(18.44 \%)$ respondents. The drawings were introduced to reduce any effect that the brand in the images, which used a Nike logo consistently, may have been having. The Brand Statistics table highlights how standard deviations of .917 for Brand (0, unbranded drawings) and .949 for Brand (1, branded images) lacked significant difference and proved to be insignificant in analysis. This was preferred as it would be acceptable to utilize the drawings moving forward and avoid the risk of including the Nike logo on images.

The attribute ranking section helped provide more context to the choice comparison tests. The first ranking mirrored the first survey, asking respondents about attribute importance on a scale of one to seven. Again, one indicated the attribute was "not important," four indicated "somewhat important," and a seven indicated the attribute was "very important." The preference for the ethical innovation (D1) was again apparent as it scored 5.78 in this section, which was the highest mean score. Subsequently, material durability (M2) followed closely with a score of 5.75. Supply chain environmental friendliness (SC2) saw the next highest score with a mean of 5.62, followed by material environmental friendliness (M1) with a score of 5.5, and SC1 (reduced resources used to manufacture, package, and deliver) received the lowest score of a 5.14. Overall, this provides further evidence of general preference for innovation. The mean scores for these innovations had a range of .64, which means these attribute importance scores are within $9.1 \%$ of each other.

The following attribute ranking section asked about what percent (on a scale of negative onehundred to one-hundred) more or less the respondent would be willing to pay for a product with the attribute present. The desire for material functionality persisted clearly as material durability (M2) saw a mean of positive $40.25 \%$. While respondents indicated that ethical innovation (D1) 
was the next most important (mean=31.29\%), this reveals that although consumers perceive ethics as important, their willingness to pay shows how necessary functionality is. Material $(\mathrm{M} 1=28.18 \%)$ and supply chain $(\mathrm{SC} 2=26.39 \%)$ environmental friendliness were within $5 \%$ of D1's score, while the lowest score again fell to SC1 (reduced resources used to manufacture, package, and deliver) with a mean of $17.16 \%$. Material innovations (M1, M2) saw a mean score $34.22 \%$, compared to supply chain innovations mean of $21.78 \%$.

The final attribute ranking section asked consumers, instead of how much they were willing to pay, how much they thought the implementation of each innovation would cost the company on the same negative one-hundred to one-hundred scale, as a percentage of the overall price of the product. The order of the mean scores was identical to the order in the willingness to pay section. Material durability (M2) had the highest mean score of 34.5\%, followed by ethical innovation (D1) with a mean of $32.17 \%$, material environmental friendliness (M1) with a mean of $29.34 \%$, supply chain environmental friendliness (SC2) with a mean of $28.69 \%$, and ending again with reduced resources used in the supply chain (SC1) with a mean score of $14.64 \%$. The mean of material innovation (M1, M2) was $31.92 \%$ compared to the supply chain innovation (SC1, SC2) mean score of $21.67 \%$.

Respondents had the option at the end of the survey to provide open ended comments. 59/103 respondents choose to comment and the 59 responses were coded into two general categories, if the respondent had a generally positive experience with the survey or if they had a generally negative experience. There was not a strict criterion, but mentions of "repetitive" or "didn't like" were coded negative while "interesting" or "made me think" were coded as positive. Out of the fifty-nine responses, forty-nine (83\%) were positive. Although a general preference for these eco-innovations has been established, these comments may be indicating more than general 
preference. While this study saw respondents from a city and school known for an overall green outlook, increased desire to understand how these innovations affect purchase preference isn't just an opportunity for research, it is what people want brands to start doing more.

\section{$\underline{\text { PSU Survey Discussion }}$}

A detailed discussion of the choice data is in the following section, but the preliminary themes revolve around similar discoveries from the attribute ranking sections. The most preferred attribute was ethical innovation (D1). The attribute importance section aligned with the overall perception of this innovation as being the most important as it had the highest attribute importance score. Material innovations (M1, M2) had equal preference in direct comparison but contrasting preference compared to other innovations. The contrasting preference was also present in the attribute rankings as M2 was always ranked over M1, but depending on preference or price sensitivity, the scale and order of preference in comparison, changed. There were mixed preferences for material (M1) and supply chain (SC2) environmental friendliness. M1 was consistently at the bottom of the attribute ranking sections, which will be an interesting area of exploration as the following discussion will reveal the equal preference between the material innovations in a direct comparison.

\section{GENERAL DISCUSSION WITH TESTABLE RESEARCH QUESTIONS}

The culmination of the literature review, industry discussion and two consumer surveys was specific research questions to be tested in a national survey. In particular, the following discussion presents the results from the PSU A/B choice tests on a scale of negative one to one (1 to 1$)$ Negative choice indicates choice of the first innovation in the comparison and positive choice indicates choice of the second innovation in the comparison. The first observation from this survey was a strong preference for ethical innovation. Overall, the innovation describing 
ethics (D1), saw the second strongest preference (D0 vs. D1=.7864) when compared in the innovation vs. no innovation section of choice test. Further, the comparison of D1 to the other innovations resulted in preference for D1, unanimously. "Increased use of environmentally friendly materials" (M1) had the weakest preference when compared to D1 with a choice score (M1 vs. D1=.2718) and "Increased use of environmentally friendly practices to manufacture, package, and deliver the product" (SC2) had a much closer preference with choice score of (SC2 vs. D1=.0777). While there was a range of preference for D1 compared to the other innovations, the implications of one innovation maintaining total preference over all others in paired comparison led to a deeper question. As ethics are preferred, how does the ethical impact of material and supply chain differ? Since D1 generalized ethics in Survey 2 to exclude difference of material or supply chain, a new test was developed to test against a generalized “environmentally sustainable practices throughout all materials and production practices". Research Question 1: Will consumers prefer ethical innovations if they lead to a decrease in environmental sustainability?

Another finding was how the overall material and supply chain innovations related to each other. When comparing, material innovation 1 (M1) and "Increased use of durable and long-lasting materials" (M2) there was no difference in overall choice (M1 vs. M2=0.00). Further, both M1 and M2 were preferred over "reduced use of resources used to manufacture, package, and deliver the product" (SC1). Environmentally friendly materials saw a small preference over SC1 (M1vs. SC1=-.0777) while durable and long-lasting materials has slightly higher choice over SC1 (M2 vs. SC1=-.1533). However, comparing the material innovations (M1, M2) to Supply Chain innovation 2, increased use of environmentally friendly practices to manufacture, package, and deliver the product, reveals a different pattern in the general choice of 
material innovations when compared to supply chain environmental friendliness (SC2). Supply chain environmental friendliness saw choice significant preference $(\mathrm{p}$-value=<.01) over environmentally friendly materials (M1 vs. SC2 $=.4369$ ). In contrast, choice was equal between durable materials (M2) and supply chain environmentally friendliness (SC2) (M2 vs. SC2=0.00) indicates much higher choice for the functional innovation in materials in this comparison.

Although increasing environmentally friendliness of supply chain practices (SC2) is preferred over increased environmental friendliness of materials (M1), there is not a preference between SC2 and increased durability of products. This relationship reveals a juxtaposition where M2 is preferred more than M1 considerably in these comparisons, but M1=M2. To better understand this relationship a second test was developed to determine if manipulating an increase/decrease of material innovation attributes results in any difference in choice. Research Question 2: Given a tradeoff between increasing and decreasing material innovations including durability, environmental friendliness, and waste, which is preferred by consumers?

Material innovation 1 and Supply Chain innovation 2 both offered "environmental friendliness", with M1 in material and SC2 in supply chain. However, consumers preferred SC2 over M1 (M1 vs. SC2=.4369). This finding is consistent with the innovation scores versus a neutral option with scores of (None vs. SC2=.8058) while (None vs. M1=.6893). To investigate the difference between the material and supply chain aspects of "environmental friendliness", a third test was developed to determine if manipulating an environmental impact score for materials and supply chain results in significant changes in preference from this finding. Research Question 3: Products with environmentally friendly supply chain innovations are preferred over products with environmentally friendly materials, given a tradeoff of an environmental impact score increasing or decreasing between the variables, which is preferred? 
Additionally, will this preference hold across different product usages for performance and lifestyle (utilitarian and hedonic)?

A final test was developed based on supply chain tier transparency theory. Seeing beyond the first tier of a supply chain has been a traditional challenge and logistical barrier, with more prevalent risks further typically further upstream due to the lack of visibility (New, 2017). The out of sight, out of mind attitudes of yesterday which led to some of these plaguing issues have begun to be erased, so do consumers care about their relative distance to the material's sourcing location or supply chain processes (manufacturing, packaging, and delivery)?

Research Question 4: As the distance increases in supply chain tiers, visibility and transparency decrease, given a tradeoff of relative distance from material sourcing and supply chain processes, is less distance preferred?

For an overview of the survey that is being developed please reference the Proposed National Survey Design section the Survey Reference Appendix. This survey utilizes aspects of each survey analyzed thus far and has been developed to answer these research questions specifically, instead of gaining an understanding of more general attitudes.

This paper aims to have marketing implications for companies in the athletic and outdoor industry as well as contributing to academic literature on sustainability impact consumer research. The industry survey presented a clear message: consumers need understanding of how companies innovate in this industry and how it can matter to them: "It has to be real and understandable," (Industry Respondent 1), there needs to be "Transparency about what is in the products they buy and who made them under what conditions," (Industry Respondent 4) and, “interestingly enough I don't believe that consumers are recognizing sustainable innovations and taking that into account when purchasing," (Industry Respondent 3). Further, simple responses 
demonstrated the potential power of asking these questions to draw awareness to these attributes. Participant 98 from survey 2 who said the survey, "Reminded me to be environmentally conscious," and participant 88 from survey 2 commented, "The questions in the survey made me rethink about my shopping habits." Participant 65 from Survey 2 summed up the consumer attitudes with a spot on closing comment, "I am glad that more companies are beginning to realize their environmental impact. More consumers need to be educated regarding their purchasing choices." Not only do the proposed research questions investigate how the industry can leverage different innovations in marketing, it also shows that the questioning process itself may be helpful to consumers. These emergent research questions will aid in understanding consumer preferences for eco-innovations. 


\section{LITERATURE REVIEW}

TABLE 1

\begin{tabular}{|c|c|c|c|}
\hline$\underline{\text { Source }}$ & $\frac{\text { Type of }}{\text { Innovation }}$ & $\underline{\text { Explanation }}$ & Consumer Finding \\
\hline $\begin{array}{l}\text { Egbue and } \\
\text { Long (2012) }\end{array}$ & Product & $\begin{array}{l}\text { Provides cross industry } \\
\text { insight into transportation/ } \\
\text { automotive industries. } \\
\text { Very similar ideas to } \\
\text { research listed above with } \\
\text { uncertainty about adopting } \\
\text { new green technology and } \\
\text { I performance compared to } \\
\text { less sustainable } \\
\text { counterparts. Sustainability } \\
\text { holds influence over } \\
\text { purchase intention because } \\
\text { of preconceived notions } \\
\text { consumers hold about } \\
\text { green products and their } \\
\text { lack of overall } \\
\text { effectiveness. }\end{array}$ & $\begin{array}{l}\text { Findings suggest that although } \\
\text { sustainability and environmental } \\
\text { benefits of EVs have a major } \\
\text { influence on EV adoption they are } \\
\text { ranked behind cost and performance. } \\
\text { Conclude that a moderate to high } \\
\text { interest in EVs exists despite several } \\
\text { reservations expressed towards EVs. } \\
\text { Attitudes towards EVs were neither } \\
\text { wholly positive nor wholly negative, } \\
\text { however, completely negative } \\
\text { attitudes to EV technology detected, } \\
\text { even minimal, should not be ignored. } \\
\text { A major potential barrier to } \\
\text { widespread EV adoption is the } \\
\text { uncertainty associated with the EV } \\
\text { battery technology and sustainability } \\
\text { of fuel source. Some of this } \\
\text { uncertainty may be attributed to } \\
\text { unfamiliarity with the EV technology } \\
\text { but may also be due to the fact that } \\
\text { some aren't convinced that EVs are a } \\
\text { better option than some currently } \\
\text { available CVs. }\end{array}$ \\
\hline $\begin{array}{l}\text { Geng et al. } \\
(2017)\end{array}$ & $\begin{array}{l}\text { Consumption } \\
\text { Motivation }\end{array}$ & $\begin{array}{l}\text { Low level of understanding } \\
\text { the idea of sustainable } \\
\text { consumption (SC) among } \\
\text { adolescents in the study, } \\
\text { yet understanding is critical } \\
\text { to effect practice of SC. } \\
\text { The benefits, specifically, } \\
\text { are what consumers need } \\
\text { to understand to motivate } \\
\text { behavior. }\end{array}$ & $\begin{array}{l}\text { Importance for businesses to develop } \\
\text { innovative and meaningful ways to } \\
\text { communicate with customers about } \\
\text { the impacts of purchases. This will } \\
\text { also serve, similarly to Sheth et al. } \\
\text { (2010), to be a good business practice } \\
\text { for the companies who choose to } \\
\text { influence mindfulness during } \\
\text { consumption. Annual sustainability } \\
\text { reports are a start mentioned in this } \\
\text { paper, but integrating eco-education \& } \\
\text { awareness into storytelling within } \\
\text { marketing initiatives, Del Pilar } \\
\text { (2017), will likely end up being the } \\
\text { most influential way to affect } \\
\text { behavior. }\end{array}$ \\
\hline
\end{tabular}




\begin{tabular}{|c|c|c|c|}
\hline $\begin{array}{l}\text { Gilbride } \\
(2014)\end{array}$ & Industry & $\begin{array}{l}\text { Utilizes Framework for } \\
\text { Strategic Sustainable } \\
\text { Development (FSSD) to } \\
\text { assess current reality of } \\
\text { industry and, utilizing eight } \\
\text { sustainability principles } \\
\text { (Concentrations of } \\
\text { substances extracted from } \\
\text { Earth's surface, } \\
\text { concentrations of } \\
\text { substances produced by } \\
\text { society, degradation by } \\
\text { physical means, integrity, } \\
\text { influence, competence, } \\
\text { impartiality \& meaning) to } \\
\text { bridge the gap toward the } \\
\text { future. }\end{array}$ & $\begin{array}{l}\text { Both consumers and people in the } \\
\text { industry have for a shared value in } \\
\text { spending time enjoying nature. This } \\
\text { common value could potentially } \\
\text { contribute to building trusting } \\
\text { relationships between brands and } \\
\text { consumers. Outdoor industry } \\
\text { consumers are a niche market in that } \\
\text { they are willing to pay for } \\
\text { performance and quality and this can } \\
\text { be seen as an advantage for the } \\
\text { industry to try new and innovative } \\
\text { ideas. The outdoor industry has a } \\
\text { unique opportunity with a consumer } \\
\text { group that already recognizes the } \\
\text { value in outdoor activities to educate } \\
\text { and make the connection between } \\
\text { sustainability and outdoor } \\
\text { experiences. }\end{array}$ \\
\hline $\begin{array}{l}\text { Hasford, } \\
\text { and Farmer } \\
(2016) \text {. }\end{array}$ & Product & $\begin{array}{l}\text { Provides new perspective } \\
\text { on consumer perceptions of } \\
\text { CSR by comparing direct } \\
\text { competitors with more } \\
\text { socially responsible } \\
\text { products. The more } \\
\text { responsible products } \\
\text { caused more conflicting } \\
\text { opinions for the consumer } \\
\text { and potential negative } \\
\text { consequences associated. }\end{array}$ & $\begin{array}{l}\text { Pitting brands against each other, } \\
\text { moreover, highlights lack of focus and } \\
\text { the limited amount of research on } \\
\text { Athletic/Outdoor products and their } \\
\text { relationship with CSR and consumer } \\
\text { purchase preference. Reveals how } \\
\text { CSR information can cause } \\
\text { conflicting opinions from the } \\
\text { consumer, especially about athletic } \\
\text { oriented product when different } \\
\text { brands product are compared against } \\
\text { one another. }\end{array}$ \\
\hline $\begin{array}{l}\text { Joshi and } \\
\text { Rahman. } \\
(2015)\end{array}$ & $\begin{array}{l}\text { Product } \\
\text { preference }\end{array}$ & $\begin{array}{l}\text { Factors: individual } \\
\text { decision makers, emotions, } \\
\text { habits, perceived consumer } \\
\text { effectiveness, perceived } \\
\text { behavioral control, values } \\
\text { and personal norms, trust, } \\
\text { knowledge. Situational } \\
\text { factors, price, product } \\
\text { availability, subjective } \\
\text { norm/social norm \& } \\
\text { reference group, product } \\
\text { attributes, store related } \\
\text { attributes, brand image, } \\
\text { eco-labelling and } \\
\text { certification. Studies on }\end{array}$ & $\begin{array}{l}\text { Research suggests consumers may } \\
\text { care more, but there is little evidence } \\
\text { to suggest that green purchasing has } \\
\text { actually increased. Attitude vs } \\
\text { purchase behavior confluence is } \\
\text { highlighted well by analyzing relevant } \\
\text { research as this article does. Attitude } \\
\neq \text { action. Overwhelmingly, consumers } \\
\text { preferred functional attributes } \\
\text { sustainable ones and their opinions on } \\
\text { whether the product was actually } \\
\text { green or "low quality" greatly } \\
\text { influenced their purchasing patterns. }\end{array}$ \\
\hline
\end{tabular}




\begin{tabular}{|c|c|c|c|}
\hline & & $\begin{array}{l}\text { green purchase intention \& } \\
\text { green purchase behavior. } \\
\text { High environmental } \\
\text { concern \& green attributes } \\
\text { are the two major motives. } \\
\text { Simple \& user friendly info } \\
\text { is important }\end{array}$ & \\
\hline $\begin{array}{l}\text { Ki and Kim } \\
\text { (2016) }\end{array}$ & $\begin{array}{l}\text { Product/ } \\
\text { Consumption } \\
\text { preference }\end{array}$ & $\begin{array}{l}\text { Aims to place less } \\
\text { emphasis on the } \\
\text { conspicuous desires of } \\
\text { luxury purchases, and } \\
\text { focuses on the timelessness } \\
\& \text { durable quality aspects. }\end{array}$ & $\begin{array}{l}\text { Consumers who buy luxury items to } \\
\text { communicate their deepest intrinsic } \\
\text { values to feel satisfied with such a } \\
\text { conscious consumption decision. } \\
\text { Personalization of product could lead } \\
\text { to increases in purchasing intentions. } \\
\text { Seeking intrinsic values of personal } \\
\text { style \& social consciousness allow } \\
\text { consumers to express concern for } \\
\text { societal issues via tangible purchases } \\
\text { and taking companies ethics into } \\
\text { consideration before purchasing. } \\
\text { Environmental factors were less } \\
\text { prevalent for the participants } \\
\text { purchasing motivation in this study. }\end{array}$ \\
\hline $\begin{array}{l}\text { Klaiman et } \\
\text { al. (2017) }\end{array}$ & $\begin{array}{l}\text { Package } \\
\text { Characteristics }\end{array}$ & $\begin{array}{l}\text { Measured shopping habits, } \\
\text { recycling behavior and } \\
\text { attitude toward recycling. } \\
\text { Also took demographics } \\
\text { into account to examine } \\
\text { how they influence motives } \\
\text { to recycle. Evaluated } \\
\text { drivers and barriers w/ } 20 \\
\text { choice scenarios. }\end{array}$ & $\begin{array}{l}\text { Information treatments did not } \\
\text { significantly affect consumer } \\
\text { recycling behavior, but did alter } \\
\text { preference for packaging material. } \\
\text { Information targeted on the energy } \\
\text { savings benefits of recycling or non- } \\
\text { targeted, delivered via video or } \\
\text { infographic, can alter consumer } \\
\text { preferences for packaging material. } \\
\text { While this is not A\&O focused, this } \\
\text { shows outside relevance and gives } \\
\text { insight about on how demographics } \\
\text { can affect preferences to recycle. The } \\
\text { opportunity cost of cleaning the } \\
\text { material was more influential than the } \\
\text { number of parts or material. After } \\
\text { identifying barriers, this study reveals } \\
\text { information treatment can affect } \\
\text { preference, but more research is } \\
\text { needed to understand how to influence } \\
\text { behavior. }\end{array}$ \\
\hline
\end{tabular}




\begin{tabular}{|c|c|c|c|}
\hline $\begin{array}{l}\text { Lin and } \\
\text { Chang } \\
(2012)\end{array}$ & Product & $\begin{array}{l}\text { Echo's findings of } \\
\text { sustainability liability } \\
\text { associated with marketing } \\
\text { green products. Function is } \\
\text { more important than any } \\
\text { green attribute. Uses } \\
\text { example of more } \\
\text { environmentally friendly } \\
\text { soaps and amount used } \\
\text { after purchase, which tends } \\
\text { to be more because of } \\
\text { perceived inferiority. }\end{array}$ & $\begin{array}{l}\text { Similar to Luchs, marketers should } \\
\text { clearly label to promote the } \\
\text { effectiveness of green product to } \\
\text { overcome sustainability liability } \\
\text { associated with the marketing in } \\
\text { general. P. } 132 \text { reveals that product } \\
\text { effectiveness information, such as } \\
\text { credible endorsement can overcome } \\
\text { the perception of a green products } \\
\text { ineffectiveness and eliminate the } \\
\text { differential usage between green and } \\
\text { regular products. }\end{array}$ \\
\hline $\begin{array}{l}\text { Luchs et al } \\
\text { (2010) }\end{array}$ & Product & $\begin{array}{l}\text { By examining } \\
\text { sustainability as something } \\
\text { that has effect on the } \\
\text { consumer's perception of } \\
\text { other product attributes, } \\
\text { this article was able to } \\
\text { reveal the potential liability } \\
\text { sustainability has on } \\
\text { consumer's willingness to } \\
\text { pay. }\end{array}$ & $\begin{array}{l}\text { The degree to which sustainability } \\
\text { enhances preference depends on the } \\
\text { type of benefit consumers most value } \\
\text { for the product category in question. } \\
\text { Consumers associate higher product } \\
\text { ethicality with gentleness-related } \\
\text { attributes and lower product ethicality } \\
\text { with strength-related attributes. }\end{array}$ \\
\hline $\begin{array}{l}\text { Lundblad } \\
\text { and Davies. } \\
\text { (2016) }\end{array}$ & $\begin{array}{l}\text { Product } \\
\text { attributes, } \\
\text { consequences } \\
\text { \& values }\end{array}$ & $\begin{array}{l}\text { This research illuminates } \\
\text { how sustainable } \\
\text { consumption could become } \\
\text { a norm behavior }\end{array}$ & $\begin{array}{l}\text { Benefits including better health, self- } \\
\text { esteem, responsibility, value for } \\
\text { money, protecting the planet and } \\
\text { social justice were identified as } \\
\text { primary motivators but these altruistic } \\
\text { motives were not the pure reason for } \\
\text { consumption. Moving to feel better } \\
\text { about oneself and guilt free are also } \\
\text { important to consider along with } \\
\text { comfort and style (functional } \\
\text { attributes). The patterns identified } \\
\text { include: buy less, self-expression/ } \\
\text { esteem, health, the environment, } \\
\text { accomplishments and social justice. }\end{array}$ \\
\hline
\end{tabular}




\begin{tabular}{|c|c|c|c|}
\hline $\begin{array}{l}\text { New York } \\
\text { Times } \\
\text { International } \\
\text { Luxury } \\
\text { Conference } \\
(2016)\end{array}$ & $\begin{array}{l}\text { Integrating } \\
\text { eco- } \\
\text { innovation } \\
\text { into the fabric } \\
\text { of business }\end{array}$ & $\begin{array}{l}\text { This video highlights } \\
\text { Adidas collaboration with } \\
\text { Parley for the Oceans, } \\
\text { Tiffany's Diamonds work } \\
\text { to improve their CSR, \& } \\
\text { Brunello Cucinelli's vision } \\
\text { to incorporate eco- } \\
\text { innovation into the soul of } \\
\text { his fashion brand. Each } \\
\text { executive highlights the } \\
\text { different ways that their } \\
\text { CSR has developed and } \\
\text { grown. A striking example } \\
\text { is that when Adidas } \\
\text { announced their } \\
\text { collaboration with Parley, } \\
\text { this campaign hit } 5 \text { billion } \\
\text { views, which was almost } \\
\text { twice the amount they } \\
\text { received when announcing } \\
\text { their collaboration with } \\
\text { Kanye West. }\end{array}$ & $\begin{array}{l}\text { This example shows that consumers } \\
\text { do care and whether these executives } \\
\text { have the data to back they care or not, } \\
\text { sustainability has become a metric to } \\
\text { measure financial performance and } \\
\text { investors love it too. Kowalski, } \\
\text { Chairman of the Board at Tiffany's, } \\
\text { says they had little data to back their } \\
\text { instinct the consumer cared, but it } \\
\text { ended up paying off in droves. } \\
\text { Whether the data backs the consumer } \\
\text { cares or not, the executives are driven } \\
\text { to sell products that are meaningful } \\
\text { and mitigate environmental impact as } \\
\text { much as possible. "you have to be } \\
\text { compelling and passionate about your } \\
\text { argument but sustainability is not even } \\
\text { questionable as is I meaningfulness to } \\
\text { the consumer."-Eric Liedtke }\end{array}$ \\
\hline $\begin{array}{l}\text { Outdoor } \\
\text { Industry } \\
\text { Association } \\
(2015)\end{array}$ & Consumer & $\begin{array}{l}\text { Segmentation of } \\
\text { consumers into The } \\
\text { Achiever, The Outdoor } \\
\text { Native, The Urban Athlete, } \\
\text { The Aspirational Core, The } \\
\text { Athleisurist, The Sideliner } \\
\text { and The Complacent. Each } \\
\text { segment represents } \\
\text { differences in category } \\
\text { spending, outdoor } \\
\text { engagement and pose } \\
\text { different strategies to best } \\
\text { deliver value. }\end{array}$ & $\begin{array}{l}34 \% \text { of outdoor consumers live in } \\
\text { cities and those consumers are young, } \\
\text { ethnically diverse, active and spend } \\
\text { the most on outdoor gear. The } \\
\text { industry helps older consumers stay } \\
\text { engaged and helps parents engage } \\
\text { kids to keep a large pipeline of } \\
\text { consumers incoming for the } \\
\text { foreseeable future. Outreach that } \\
\text { addresses universal needs such as } \\
\text { sunshine/fresh air and social } \\
\text { engagement will resonate well. Brand } \\
\text { familiarity is critical. } 46 \% \text { of } \\
\text { consumers are willing to pay more for } \\
\text { durability, } 42 \% \text { are willing to pay for } \\
\text { highest quality. }\end{array}$ \\
\hline $\begin{array}{l}\text { Peloza and } \\
\text { Shang } \\
(2010)\end{array}$ & $\begin{array}{l}\text { CSR Lit } \\
\text { Review }\end{array}$ & $\begin{array}{l}\text { Creating a change from } \\
\text { simply understanding of } \\
\text { when CSR facilitates } \\
\text { exchange between a firm } \\
\text { and consumer to an } \\
\text { examination of how CSR } \\
\text { can create value for } \\
\text { consumers, marketing }\end{array}$ & $\begin{array}{l}\text { Overall need for more deliberate and } \\
\text { precise generalizations in CSR } \\
\text { research, and an increased focus on } \\
\text { the source of stakeholder value } \\
\text { provided by CSR activities. A focus } \\
\text { on CSR activities as a source of self- } \\
\text { oriented value for consumers provides } \\
\text { an opportunity for marketers to create }\end{array}$ \\
\hline
\end{tabular}




\begin{tabular}{|c|c|c|c|}
\hline & & $\begin{array}{l}\text { researchers can make a } \\
\text { meaningful impact in the } \\
\text { literature examining the } \\
\text { business case for CSR. }\end{array}$ & $\begin{array}{l}\text { differentiation and augment what is a } \\
\text { dominant emphasis on other-oriented } \\
\text { value in CSR research. }\end{array}$ \\
\hline $\begin{array}{l}\text { Retail } \\
\text { TouchPoints } \\
(2016)\end{array}$ & $\begin{array}{l}\text { Consumer, } \\
\text { Industry \& } \\
\text { Product }\end{array}$ & $\begin{array}{l}\text { Explains different types of } \\
\text { CSR initiatives for retail } \\
\text { companies and the effect } \\
\text { they have on the } \\
\text { environment or society. }\end{array}$ & $\begin{array}{l}\text { Reveals how consumers are starting to } \\
\text { care more about sustainability. Not } \\
\text { just the company or brand, but the } \\
\text { product itself and the supply chain } \\
\text { and sourcing practices that come with } \\
\text { it. }\end{array}$ \\
\hline $\begin{array}{l}\text { Sheth et al. } \\
\text { (2010) }\end{array}$ & $\begin{array}{l}\text { Product, Price, } \\
\text { Promotion \& } \\
\text { Place }\end{array}$ & $\begin{array}{l}\text { MC Oriented Marketing: } \\
\text { Product-offer more durable } \\
\text { attributes and replicable } \\
\text { options. New product } \\
\text { should innovate, not } \\
\text { change superficially. } \\
\text { Price-arguably the best } \\
\text { mechanism to regulate } \\
\text { demand. Emphasis should } \\
\text { not be "cheap", but quality } \\
\text { and value } \\
\text { Promotion-used for } \\
\text { education to reduce } \\
\text { wastefulness and repetitive } \\
\text { consumption. } \\
\text { Place-Easier access to } \\
\text { service/repairs and options } \\
\text { to reuse }\end{array}$ & $\begin{array}{l}\text { Fostering mindful consumption gives } \\
\text { consumer reason to care for } \\
\text { themselves, the community, and } \\
\text { nature. This translates into } \\
\text { behaviorally tempering the self- } \\
\text { defeating excesses associated with } \\
\text { acquisitive, repetitive and aspirational } \\
\text { consumption. Align consumer self- } \\
\text { interest with business self-interest to } \\
\text { serve mutual sustainable interest. }\end{array}$ \\
\hline $\begin{array}{l}\text { The Nielsen } \\
\text { Company } \\
(2015)\end{array}$ & Consumer & $\begin{array}{l}\text { Overview of millennials } \\
\text { purchasing drivers and } \\
\text { their desires to associate } \\
\text { themselves with brands } \\
\text { who identify with similar } \\
\text { values. Evaluate } \\
\text { differences of those willing } \\
\text { to pay more to align with } \\
\text { those values versus the } \\
\text { global average of typical } \\
\text { consumers }\end{array}$ & $\begin{array}{l}\text { From } 55 \% \text { in } 2014 \text { to } 72 \% 2015 \text {, } \\
\text { Millennials increased their purchase } \\
\text { preference for brands committed to } \\
\text { positive social and environmental } \\
\text { impact. Other generations are seeing } \\
\text { increases in WTP, but none as high as } \\
\text { the younger generations. For those } \\
\text { willing to spend more, findings show } \\
\text { that personal intrinsic values are far } \\
\text { more important than personal benefits, } \\
\text { such as cost or convenience. While } \\
\text { this contrasts some of the literature }\end{array}$ \\
\hline
\end{tabular}




\begin{tabular}{|l|l|l|l|}
\hline & & $\begin{array}{l}\text { around this topic, it's interesting } \\
\text { perspective. }\end{array}$ \\
& & \\
\hline
\end{tabular}

TABLE 2

\begin{tabular}{|c|c|}
\hline \multicolumn{2}{|l|}{ Eco-Innovations in Product \& Supply Chain: } \\
\hline 1. Knitted Shoe Uppers-Reducing material waste by up to $60 \%$ & $\begin{array}{l}\text { Material/ Supply } \\
\text { Chain }\end{array}$ \\
\hline $\begin{array}{l}\text { 2. PFC Free Apparel/Shoes (Columbia)-Leaves no trace particles in } \\
\text { the environment }\end{array}$ & Material \\
\hline $\begin{array}{l}\text { 3. Nike Grind-Grinded up old shoes reused in shoes, apparel \& } \\
\text { surfaces such as tracks }\end{array}$ & $\begin{array}{l}\text { Material/ Supply } \\
\text { Chain }\end{array}$ \\
\hline $\begin{array}{l}\text { 4. Unannounced Factory Audits-Social responsibility to ensure proper } \\
\text { working conditions }\end{array}$ & Ethics \\
\hline $\begin{array}{l}\text { 5. Parley for the Oceans-Adidas recycled ocean plastic woven into a } \\
\text { shoe upper }\end{array}$ & $\begin{array}{l}\text { Material/Supply } \\
\text { Chain }\end{array}$ \\
\hline $\begin{array}{l}\text { 6. 3D/"4D" Printed Shoes-Reduced material waste and transportation } \\
\text { distance for less carbon offset }\end{array}$ & Supply Chain \\
\hline 7. Various Brand HQ's Running on Renewable energy & Supply Chain \\
\hline $\begin{array}{l}\text { 8. Dry Dying Processes-saves immense amount of water typically } \\
\text { used in the dying process }\end{array}$ & Supply Chain \\
\hline $\begin{array}{l}\text { 9. Adidas Biosteel-15\% lighter in weight than conventional synthetic } \\
\text { fibers, potential to be the strongest fully natural material available. }\end{array}$ & Material \\
\hline $\begin{array}{l}\text { 10. Adidas Speedfactory-in Germany \& Atlanta. Source more locally } \\
\text { and limit transportation }\end{array}$ & Supply Chain \\
\hline $\begin{array}{l}\text { 11. Patagonia provides info on website about exactly where each part } \\
\text { of every product comes from and the environmental impact it may } \\
\text { have }\end{array}$ & $\begin{array}{l}\text { Material/ Supply } \\
\text { Chain }\end{array}$ \\
\hline 12. BCI Cotton-Used throughout industry & $\begin{array}{l}\text { Material/ Supply } \\
\text { Chain }\end{array}$ \\
\hline $\begin{array}{l}\text { 13. Reduction of use of synthetic microfibers that stay behind and } \\
\text { damage environment }\end{array}$ & Material \\
\hline 14. Industry Wide Restricted Substance List (RSL) & Supply Chain \\
\hline
\end{tabular}




\section{Appendix:}

\begin{tabular}{|l|l|}
\hline \multicolumn{2}{|c|}{ Industry Survey Innovations } \\
\hline Product & Notes \\
\hline re-threads & end of life recycling \\
\hline eco-jacket & recycled materials \\
\hline responsible down & \\
\hline Recycled polyester & \\
\hline Bluesign & "sustainable textile production" \\
\hline Design Process & pattern efficiency \\
\hline Dyeless & \\
\hline Waterless & \\
\hline Chemical makeup & \\
\hline Functionality & Durability \\
\hline Composite & \\
\hline Regrind & Recycled materials \\
\hline Zero Waste & \\
\hline Technology & \\
\hline Supply Chain & Notes \\
\hline Responsible Sourcing & Down, BCI Cotton \\
\hline Closed Loop & \\
\hline Recycling & \\
\hline Manufacturing & \\
\hline Speed to market & \\
\hline Limit micro-pollution & PFC's \\
\hline Limit production pollution & \\
\hline Carbon Footprint & \\
\hline Packaging & \\
\hline Transportation Costs & \\
\hline Proximity to product production & \\
\hline Zero Waste & \\
\hline Logistics & \\
\hline Who made the product & labor ethics \\
\hline Social Programs & \\
\hline & \\
\hline
\end{tabular}




\section{Pilot Survey Innovation Discussion}

Explanation, example, or industry relevance of each innovation:

1. Materials devoid of wasteful or harmful chemicals. The industry survey presented chemical makeup, transparency of what goes into products, circular economy, closed loop products and more natural sourcing as. "Restricted Substance List (Restricted Substance List) is intended to provide apparel and footwear companies with information related to regulations and laws that restrict or ban certain chemicals and substances in finished home textile, apparel, and footwear products around the world. Updated on a regular basis," (American Apparel \& Footwear Association, 2018).

2. Materials that can be traced to ensure ethical sourcing. Industry survey revealed not only less harmful materials but also being able to understand where they come from. "The Better Cotton Initiative (BCI Quarterly Report) is the largest cotton sustainability program in the world. Last year, with I partners, BCI provided training on more sustainable agricultural practices to close to 1.6 million farmers from 23 countries and mobilized $€ 8.9$ million in field-level investment. BCI is truly a global effort, encompassing organizations all the way from farms to fashion and textile brands, driving the cotton sector towards sustainability," (Better Cotton Initiative, 2018).

3. Less materials, leaving behind less waste. Nike's Flyknit material is an innovation (Nike Innovation, 2016) for shoe upper can reduce material waste by about $60 \%$ compared to the typical cut and sew methods of production. Many companies have followed suit.

4. Materials that have been repurposed or recycled. Multiple products or company specific materials were mentioned in the industry survey that had to do with recycling: "regrind, composite "flyleather", closed loop, recycled polyester, re-threads and eco-jacket". 
Renewable Workshop is a Portland company that takes in damaged or unsold goods from various brands and is able to repair, upcycle, or recycle based on the condition. These goods can then be sold at discounted rates second hand or transformed into something useful.

5. Durable materials that are designed to last a long time. Luchs et al. (2010) suggests consumers associate ethicality with gentle-related attributes and elaborates with the idea that lacking ethicality can be associated with "getting the job done", regardless if there is a cost to others. Industry survey mentioned adding value with sustainability but not compromising functionality. Raises the question if consumers understand the idea of "long lasting" as sustainable, unable to answer.

1. Manufacturing in a factory with ethical social standards. Ethicality and social standards mentioned throughout industry survey. Social health and justice are potential motivators for sustainable consumption practices (Lundblad and Davies, 2016). This is also completely free of brand and is clearly understood by consumers. Geng et al. (2017) proposes that the low level of understanding of sustainable consumption can be overcome with information that consumers understand and will be motivated by. These ideas helped this innovation be key to focus on.

2. Less and/or recycled packaging materials. Packaging was mentioned one time but represents another easily understandable part of the process that consumers can understand. Further, Klaiman et al. (2017) researched packaging characteristics and information treatments that influenced consumer's preference for different packaging material or willingness to engage in recycling.

3. Delivery process to reduce environmental impact. "Transportation costs (carbon footprint), direct to consumer" and introducing the idea of "scaling technology" are ideas from the 
industry survey that relate to reducing the overall impact and carbon footprint the transportation process has. Scaling technology was insightful because, for any of these innovations to have impact, they need to be scalable. Transportation efficiency is being seen readily with electric vehicles to give consumer familiarity with the topic, which likely contributed to a higher preference.

4. Manufacturing close to location of customer. The industry survey also showed "speeding up production times and ensuring close proximity to product production" is similar to increasing transportation efficiency, but focuses on the production itself and allowing the geographic location be more of an innovation. While the explanation of this concept may help to the understanding, the description/information given in the survey may not have connected with survey respondents on the level that was intended.

5. Production utilizing clean energy and without toxins "manufacturing with clean energy". Mentions of "closed loop, water, waste and carbon" in the industry interview point at ensuring the power and natural resources (other than product materials) that are involved throughout the supply chain are less harmful. This provides some counter to the innovation on the product side that includes the RSL/materials being devoid of harmful chemicals. 


\section{Pilot Survey Respondents Choice}

*Pilot Survey graphics note: scale is from one to two. One indicates choice of first option in survey (choice without any changes or innovations) and two indicates choice of the second option (choice with innovation description). A score of one would indicate no preference for innovation and a two would be full preference for innovations. The following three graphics will utilize this scale*

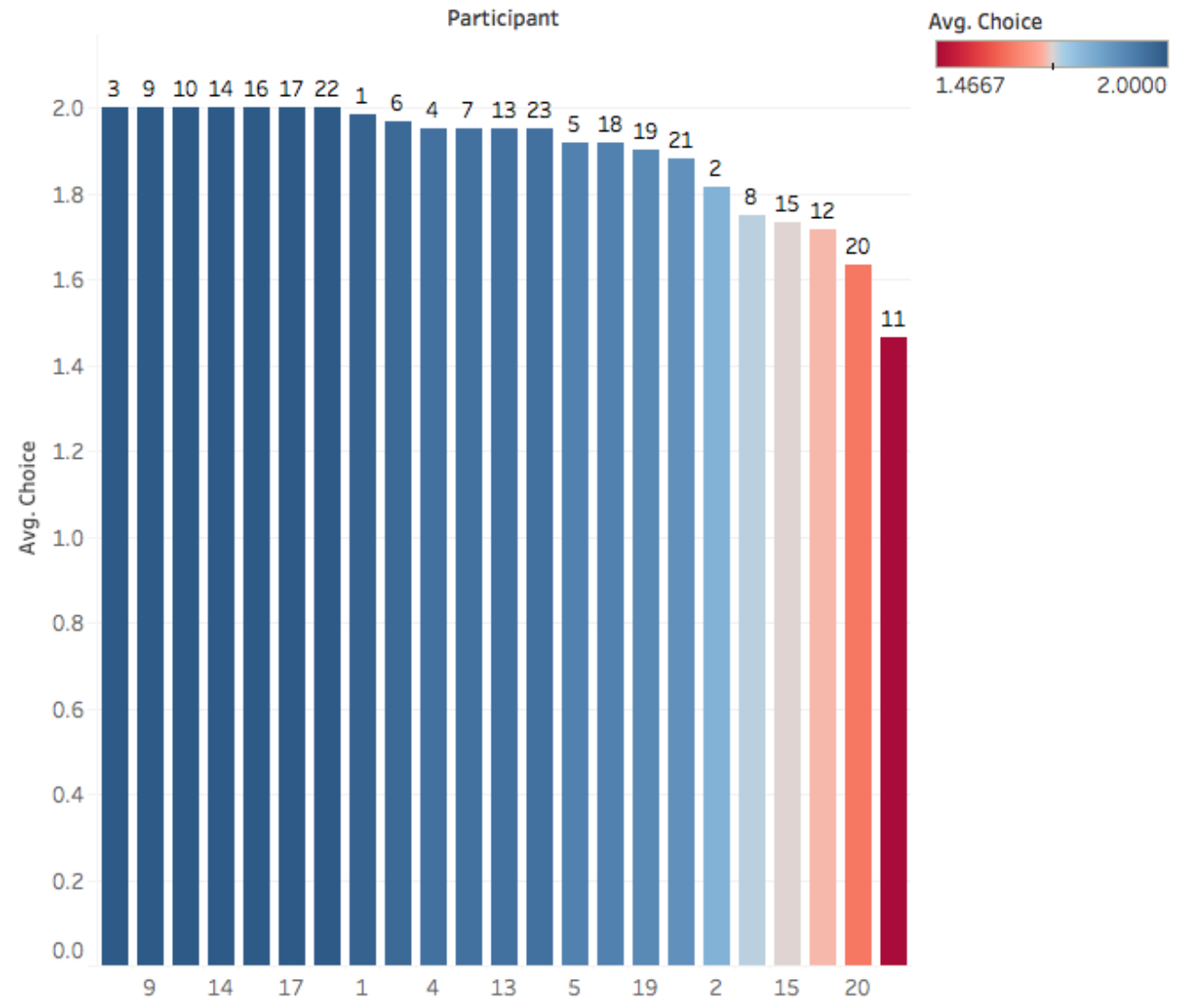

Average of Choice for each Participant. Color shows average of Choice. The marks are labeled by Participant. 


\section{Pilot Survey Product Choice}

\begin{tabular}{|c|c|c|c|c|c|c|c|c|c|}
\hline \multirow[b]{2}{*}{ Participant } & \multirow[b]{2}{*}{ Jacket A } & \multicolumn{5}{|c|}{ Product } & \multicolumn{3}{|c|}{ Avg. Choice } \\
\hline & & Jacket B & Jacket C & Shoe A & Shoe B & Shoe C & Grand To.. & & \\
\hline 3 & 2.0000 & 2.0000 & 2.0000 & 2.0000 & 2.0000 & 2.0000 & 2.0000 & 1.3000 & 2.0000 \\
\hline 9 & 2.0000 & 2.0000 & 2.0000 & 2.0000 & 2.0000 & 2.0000 & 2.0000 & & \\
\hline 10 & 2.0000 & 2.0000 & 2.0000 & 2.0000 & 2.0000 & 2.0000 & 2.0000 & & \\
\hline 14 & 2.0000 & 2.0000 & 2.0000 & 2.0000 & 2.0000 & 2.0000 & 2.0000 & & \\
\hline 16 & 2.0000 & 2.0000 & 2.0000 & 2.0000 & 2.0000 & 2.0000 & 2.0000 & & \\
\hline 17 & 2.0000 & 2.0000 & 2.0000 & 2.0000 & 2.0000 & 2.0000 & 2.0000 & & \\
\hline 22 & 2.0000 & 2.0000 & 2.0000 & 2.0000 & 2.0000 & 2.0000 & 2.0000 & & \\
\hline 1 & 2.0000 & 2.0000 & 2.0000 & 2.0000 & 1.9000 & 2.0000 & 1.9833 & & \\
\hline 6 & 2.0000 & 2.0000 & 1.9000 & 1.9000 & 2.0000 & 2.0000 & 1.9667 & & \\
\hline 4 & 2.0000 & 1.9000 & 1.9000 & 2.0000 & 1.9000 & 2.0000 & 1.9500 & & \\
\hline 7 & 2.0000 & 2.0000 & 1.9000 & 2.0000 & 1.9000 & 1.9000 & 1.9500 & & \\
\hline 13 & 2.0000 & 2.0000 & 1.9000 & 2.0000 & 1.9000 & 1.9000 & 1.9500 & & \\
\hline 23 & 2.0000 & 1.9000 & 2.0000 & 1.9000 & 1.9000 & 2.0000 & 1.9500 & & \\
\hline 5 & 1.8000 & 1.9000 & 2.0000 & 2.0000 & 1.8000 & 2.0000 & 1.9167 & & \\
\hline 18 & 2.0000 & 1.9000 & 1.7000 & 2.0000 & 1.9000 & 2.0000 & 1.9167 & & \\
\hline 19 & 1.9000 & 1.9000 & 1.9000 & 1.9000 & 1.9000 & 1.9000 & 1.9000 & & \\
\hline 21 & 1.9000 & 2.0000 & 1.8000 & 1.9000 & 2.0000 & 1.7000 & 1.8833 & & \\
\hline 2 & 1.9000 & 1.8000 & 1.8000 & 1.8000 & 1.7000 & 1.9000 & 1.8167 & & \\
\hline 8 & 1.8000 & 1.8000 & 1.7000 & 1.9000 & 1.7000 & 1.6000 & 1.7500 & & \\
\hline 15 & 1.7000 & 1.8000 & 1.6000 & 1.8000 & 1.7000 & 1.8000 & 1.7333 & & \\
\hline 12 & 1.7000 & 1.7000 & 1.8000 & 1.7000 & 1.4000 & 2.0000 & 1.7167 & & \\
\hline 20 & 1.6000 & 1.4000 & 1.6000 & 1.7000 & 1.6000 & 1.9000 & 1.6333 & & \\
\hline 11 & 1.7000 & 1.3000 & 1.6000 & 1.4000 & 1.4000 & 1.4000 & 1.4667 & & \\
\hline Grand Total & 1.9130 & 1.8826 & 1.8739 & 1.9087 & 1.8522 & 1.9130 & 1.8906 & & \\
\hline
\end{tabular}

Average A: 1.9109

Average B: 1.8674

Average C: 1.8935

Range: .0435 w/in 2.2\%

\section{Pilot Survey Product Standard Deviation}

\begin{tabular}{|c|c|c|c|c|c|c|c|c|c|}
\hline \multirow[b]{2}{*}{ Participant } & \multirow[b]{2}{*}{ Jacket A } & \multicolumn{5}{|c|}{ Product } & \multicolumn{3}{|c|}{ Std. dev. of Choice } \\
\hline & & Jacket B & Jacket C & Shoe A & Shoe B & Shoe C & Grand To.. & & \\
\hline 3 & 0.0000 & 0.0000 & 0.0000 & 0.0000 & 0.0000 & 0.0000 & 0.0000 & 0.0000 & 0.5164 \\
\hline 9 & 0.0000 & 0.0000 & 0.0000 & 0.0000 & 0.0000 & 0.0000 & 0.0000 & & \\
\hline 10 & 0.0000 & 0.0000 & 0.0000 & 0.0000 & 0.0000 & 0.0000 & 0.0000 & & \\
\hline 14 & 0.0000 & 0.0000 & 0.0000 & 0.0000 & 0.0000 & 0.0000 & 0.0000 & & \\
\hline 16 & 0.0000 & 0.0000 & 0.0000 & 0.0000 & 0.0000 & 0.0000 & 0.0000 & & \\
\hline 17 & 0.0000 & 0.0000 & 0.0000 & 0.0000 & 0.0000 & 0.0000 & 0.0000 & & \\
\hline 22 & 0.0000 & 0.0000 & 0.0000 & 0.0000 & 0.0000 & 0.0000 & 0.0000 & & \\
\hline 1 & 0.0000 & 0.0000 & 0.0000 & 0.0000 & 0.3162 & 0.0000 & 0.1291 & & \\
\hline 6 & 0.0000 & 0.0000 & 0.3162 & 0.3162 & 0.0000 & 0.0000 & 0.1810 & & \\
\hline 4 & 0.0000 & 0.3162 & 0.3162 & 0.0000 & 0.3162 & 0.0000 & 0.2198 & & \\
\hline 7 & 0.0000 & 0.0000 & 0.3162 & 0.0000 & 0.3162 & 0.3162 & 0.2198 & & \\
\hline 13 & 0.0000 & 0.0000 & 0.3162 & 0.0000 & 0.3162 & 0.3162 & 0.2198 & & \\
\hline 23 & 0.0000 & 0.3162 & 0.0000 & 0.3162 & 0.3162 & 0.0000 & 0.2198 & & \\
\hline 5 & 0.4216 & 0.3162 & 0.0000 & 0.0000 & 0.4216 & 0.0000 & 0.2787 & & \\
\hline 18 & 0.0000 & 0.3162 & 0.4830 & 0.0000 & 0.3162 & 0.0000 & 0.2787 & & \\
\hline 19 & 0.3162 & 0.3162 & 0.3162 & 0.3162 & 0.3162 & 0.3162 & 0.3025 & & \\
\hline 21 & 0.3162 & 0.0000 & 0.4216 & 0.3162 & 0.0000 & 0.4830 & 0.3237 & & \\
\hline 2 & 0.3162 & 0.4216 & 0.4216 & 0.4216 & 0.4830 & 0.3162 & 0.3902 & & \\
\hline 8 & 0.4216 & 0.4216 & 0.4830 & 0.3162 & 0.4830 & 0.5164 & 0.4367 & & \\
\hline 15 & 0.4830 & 0.4216 & 0.5164 & 0.4216 & 0.4830 & 0.4216 & 0.4459 & & \\
\hline 12 & 0.4830 & 0.4830 & 0.4216 & 0.4830 & 0.5164 & 0.0000 & 0.4544 & & \\
\hline 20 & 0.5164 & 0.5164 & 0.5164 & 0.4830 & 0.5164 & 0.3162 & 0.4860 & & \\
\hline 11 & 0.4830 & 0.4830 & 0.5164 & 0.5164 & 0.5164 & 0.5164 & 0.5031 & & \\
\hline Grand Total & 0.2824 & 0.3226 & 0.3327 & 0.2887 & 0.3557 & 0.2824 & 0.3123 & & \\
\hline
\end{tabular}

Average A: .2856

Average B: .3392

Average C: .3076

Range: .0536 w/in 5.4\% 


\section{Pilot Survey Innovation Choice}

Innovation

Participant Product 1 Product 2 Product 3 Product 4 Product 5 Supply 1 10 14 16

11 Grand Total

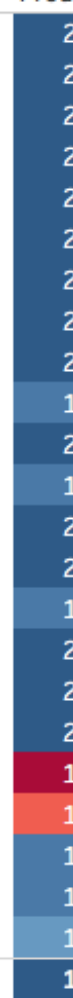

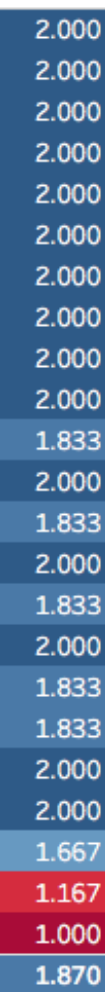

\subsection{0}

2.000

2.000

2.000

2.000

2.000

2.000

2.000

2.000

2.000

2.000

2.000

2.000

2.000

1.833

2.000

2.000

2.000

1.833

2.000

1.667

1.667
2.000

1.500

1.949

\subsection{0}

2.000

2.000

2.000

2.000

2.000

2.000

2.000

2.000

1.833

2.000

2.000

2.000

2.000

2.000

2.000

2.000

1.833

2.000

2.000

2.000

1.333

1.833

1.949

2.000

2.000

2.000

2.000

2.000

2.000

2.000

2.000

2.000

2.000

2.000

2.000

1.833

2.000

1.833

1.667

1.500

1.833

1.833

2.000

2.000
1.667

1.667
2.000

2.000

1.920

\subsection{0}

2.000

2.000

2.000

2.000

2.000

2.000

2.000

2.000

2.000

2.000

2.000

2.000

2.000

2.000

2.000

1.667

1.833

1.833

2.000

1.500

1.333

1.500

1.899
Supply 2

2.000

2.000

2.000

2.000

2.000

2.000

2.000

2.000

1.667

1.833

2.000

1.667

2.000

1.500

2.000

1.333

1.833

1.167

2.000

1.000

1.000

1.167

1.000

1.739 upply 3 Supply 4 Supply 5 Grand To..

$2.000 \quad 2.000$

$2.000 \quad 2.000$

$2.000 \quad 2.000$

$2.000 \quad 2.000$

$2.000 \quad 2.000$

$2.000 \quad 2.000$

$2.000 \quad 2.000$

$2.000 \quad 2.000$

$2.000 \quad 2.000$

$2.000 \quad 2.000$

\begin{tabular}{|l|l|}
2.000 & 1.667
\end{tabular}

$2.000 \quad 2.000$

$\begin{array}{ll}1.833 & 2.000\end{array}$

\begin{tabular}{|l|l|}
2.000 & 1.667
\end{tabular}

$2.000 \quad 2.000$

$2.000 \quad 2.000$

$2.000 \quad 2.000$

\begin{tabular}{|l|l|}
\hline 2.000 & 1.667
\end{tabular}

\begin{tabular}{ll|}
1.833 & 1.333 \\
\hline
\end{tabular}

$2.000 \quad 1.167$

2.000

2.000

2.000
1.667

1.667
1.667

1.957
2.000

2.000

2.000

2.000

2.000

2.000

2.000

1.833

2.000

2.000

2.000

2.000

2.000

2.000

1.833

2.000

2.000

2.000

1.833

1.833
1.833

1.833

\begin{tabular}{ll}
1.500 & 1.500 \\
\hline 1.833 & 2.000
\end{tabular}

1.333

1.167

1.913
Avg. Choice

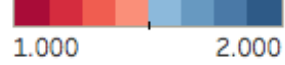

Average of Choice broken down by Innovation vs. Participant. Color shows average of Choice. The marks are labeled by average of Choice.

PSU Survey Question \& Data Descriptions

\begin{tabular}{|l|l|}
\hline Product & $\begin{array}{l}\text { The product that is being shown in the survey. There is a shoe and a } \\
\text { jacket. About 80\% of respondents took the version that had images (0) } \\
\text { instead of drawings (1) }\end{array}$ \\
\hline Innovation Test & $\begin{array}{l}\text { The innovation(s) that are being tested. The respondents took each } \\
\text { innovation versus "no Innovation" and against each other innovation, with } \\
\text { both products used in the survey. }\end{array}$ \\
\hline Brand & $\begin{array}{l}\text { Determines whether the product was an image (0) or drawing (1). The } \\
\text { drawing was an edited, later, version of the survey. Only change was } \\
\text { images. }\end{array}$ \\
\hline Participant & number corresponding to individual respondent \\
\hline Choice ID & See choice ID table-30 total choices in v2 \\
\hline AI_\# & $\begin{array}{l}\text { Attribute Importance. Scale of 1-7 for each innovation. 1=not important, } \\
\text { 4=somewhat important, 7=very important }\end{array}$ \\
\hline WTP_\# & Willingness to Pay. Scale of $+/-100 \%$ \\
\hline C2C_\# & Cost to company. Scale of +/- 100\% \\
\hline
\end{tabular}




\begin{tabular}{|l|l|}
\hline ActualPurchase & $\begin{array}{l}\text { Likelihood to actually purchase (s)/(j) on scale on 1-7. 1=not important, } \\
\text { 4=somewhat important, 7=very important }\end{array}$ \\
\hline ProductType & Primary use. 1 (athletic) 2 (fashion) 3 (everyday) 4 (other) \\
\hline TimesPurchased & $\begin{array}{l}\text { Actual purchases in the last 2 years. 1 (zero), 2 (one), 3 (two-four), } 4 \\
\text { (five-ten), 5 (ten or more), 6 (I don't know) }\end{array}$ \\
\hline YearBorn & 2018-(user input) =age. Need to be grouped \& bucketed* \\
\hline ZipCode & Location estimation \\
\hline EnviroConscious & 14 (yes), 15 (no), 16 (I don't know) \\
\hline $\begin{array}{l}\text { Athletic } \\
\text { Outdoorsy }\end{array}$ & Do you consider yourself? 1 (yes) 2 (no) 3 (I don't know) \\
\hline Reduce Impact & Actively reduce environmental impact? 27 (yes) 28 (no) 29 (I don't know) \\
\hline Recycling & Do you know what recycling is? 4 (yes) 5 (no) 6 (I don't know) \\
\hline
\end{tabular}

PSU Survey Product/Brand Choices

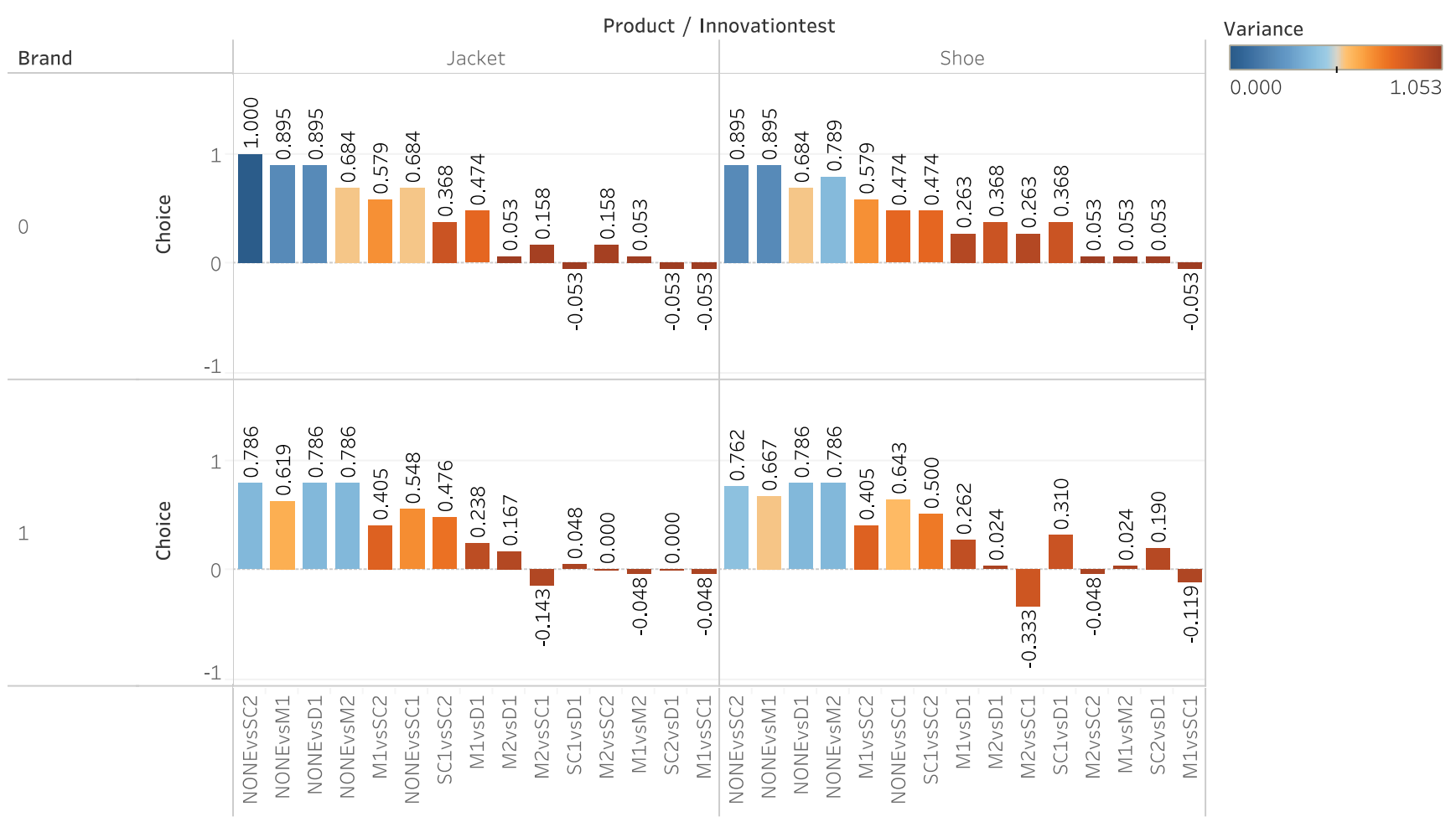


PSU Survey Attribute Pivot Tables

\begin{tabular}{|c|c|c|c|c|c|c|c|}
\hline Attribute Importance & M1 & M2 & SC1 & $\mathrm{SC} 2$ & & & TOTAL \\
\hline 0 (drawings) & & 5.63 & 5.79 & 5.32 & 5.58 & 6.00 & 5.66 \\
\hline 1 & & 5.48 & 5.74 & 5.10 & 5.63 & 5.73 & 5.53 \\
\hline TOTAL & & 5.50 & 5.75 & 5.14 & 5.62 & 5.78 & 5.56 \\
\hline
\end{tabular}

Ranking

1. D1

2. $\mathrm{M} 2$

3. $\mathrm{SC} 2$

4. M1

5. $\mathrm{SC} 1$

a. Material Innovation Average $=5.63$

b. Supply Chain Average $=5.38$

\begin{tabular}{|c|c|c|c|c|c|c|c|c|c|c|c|c|}
\hline Willingness to Pay & M1 & & M2 & & SC1 & & $\mathrm{SC} 2$ & & D1 & & TOT & \\
\hline 0 (drawings) & $\$$ & 34.58 & $\$$ & 44.05 & $\$$ & 18.53 & $\$$ & 26.95 & $\$$ & 41.11 & $\$$ & 33.04 \\
\hline 1 & $\$$ & 26.74 & $\$$ & 39.39 & $\$$ & 16.85 & $\$$ & 26.26 & $\$$ & 29.07 & $\$$ & 27.66 \\
\hline TOTAL & $\$$ & 28.18 & $\$$ & 40.25 & $\$$ & 17.16 & $\$$ & 26.39 & $\$$ & 31.29 & $\$$ & 28.65 \\
\hline
\end{tabular}

Ranking

1. $\mathrm{M} 2$

2. D1

3. M1

4. $\mathrm{SC} 2$

5. $\mathrm{SC} 1$

a. Material Innovations Average: $34.22 \%$

b. SC Innovations Average: $21.78 \%$

\begin{tabular}{|c|c|c|c|c|c|c|c|c|c|c|c|c|}
\hline Cost to Company & M1 & & M2 & & SC1 & & $\mathrm{SC} 2$ & & D1 & & TOTAL & \\
\hline 0 (drawings) & $\$$ & 36.84 & $\$$ & 44.63 & $\$$ & 16.47 & $\$$ & 34.05 & $\$$ & 41.68 & $\$$ & 34.74 \\
\hline 1 & $\$$ & 27.64 & $\$$ & 32.20 & $\$$ & 14.23 & $\$$ & 27.48 & $\$$ & 30.02 & $\$$ & 26.31 \\
\hline TOTAL & $\$$ & 29.34 & $\$$ & 34.50 & $\$$ & 14.64 & $\$$ & 28.69 & $\$$ & 32.17 & $\$$ & 27.87 \\
\hline
\end{tabular}

Ranking

1. $\mathrm{M} 2$

2. D1

3. M1

4. $\mathrm{SC} 2$

5. SC1

a. Material Innovations Average: $31.92 \%$

b. SC Innovations Average: $21.67 \%$ 
PSU Survey Similarity

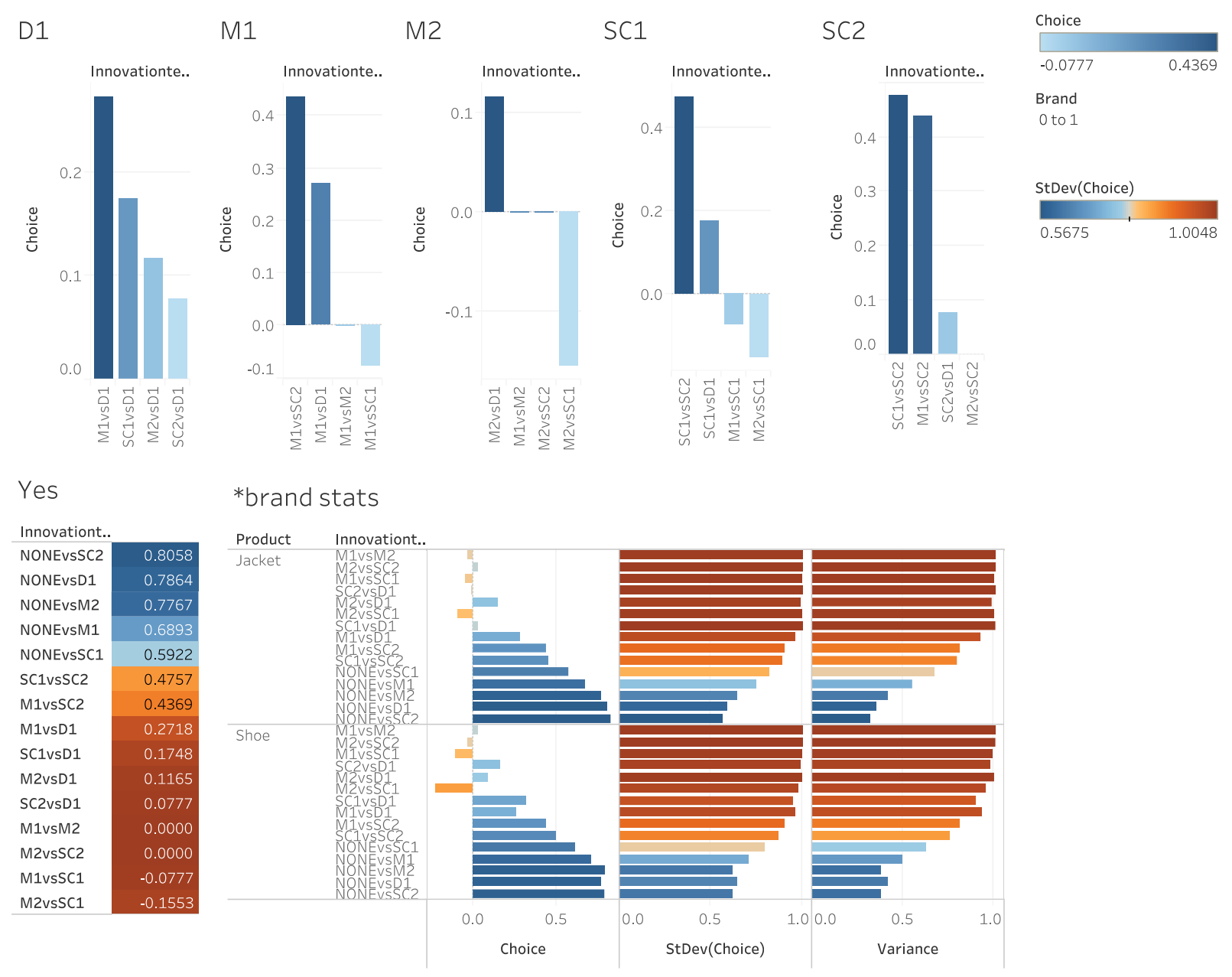

\section{SURVEY QUESTION REFERENCE APPENDIX}

\section{Full Industry Survey}

1. Has your company publicly shared any aspects of sustainability innovation with its customers? If so, what types of sustainability innovations are incorporated into currently available products or have been publicly disclosed?

2. What aspects of sustainability innovation in the athletic and outdoor industry do you expect other companies to offer in the future?

3. What aspects of sustainability innovation in the athletic and outdoor industry do you believe are most important to consumers?

4. What is your job title?

5. Do you have any additional questions or thoughts about the study? If so, please feel free to enter here: 


\title{
Industry Recruitment Protocol
}

Hello,

My name is Ethan Cotton and I am an Honors student at Portland State University. I am a Marketing and Supply/Logistics Management double major in the School of Business Administration and my research is being supported by faculty member Jacob Suher, Ph.D., Assistant Professor of Marketing and Institute of Sustainable Solutions Fellow.

My research is investigating how consumers in the athletic and outdoor industry are responding to sustainable innovations in product and supply chains. I hope to learn more about the aspects of innovations occurring within the industry and the value of these innovations for consumers. If you feel your job provides you enough perspective on the scope of this research I would like to ask you complete a short four question interview with me. This can be done over email, a phone call or in person. If you have any initial questions or concerns before starting this process please find contact info for myself and my mentor, Jacob Suher, below.

Please respond with your preferred method of contact if you wish to participate. This interview will take about fifteen minutes to complete.

Thank you in advance for your participation.

Ethan Cotton

Marketing and Supply/Logistics Management

Business Honors, Portland State University

esc2@pdx.edu

970-376-3583

Jacob Suher, Ph.D.

Assistant Professor of Marketing

The School of Business, Portland State University

jsuher@pdx.edu

503-725-9875

Industry Consent Template:

The Portland State University

\author{
Consent to Participate in Research \\ Sustainable Innovation in the A\&O Industry \\ Version 1, October 5th, 2017
}

Introduction

You are being asked to participate in a research study that is being done by Ethan Cotton, who is a student mentored by Principal Investigator, Jacob Suher from the Department of Marketing, at Portland State University in Portland, Oregon. This research is studying how consumers are responding to sustainable innovation in the athletic \&amp; outdoor industry.

You are being asked to participate in this study because you are employed in the athletic and outdoor industry

This form will explain the research study and will also explain the possible risks and benefits to you. We encourage you to talk to your family and friends before you decide to take part in this res study. If you have any questions, please ask one of the study investigators. 
What will happen if I decide to participate?

If you agree to participate, the following things will happen:

You will be asked three questions on the research topic to better understand opinions of industry experts.

How long will I be in this study?

Participation in this study will take a total of 15 minutes.

What are the risks or side effects of being in this study?

There are risks of stress, emotional distress, inconvenience and possible loss of privacy and confidentiality associated with participating in a research study.

For more information about risks and discomforts, ask the investigator.

What are the benefits to being in this study?

There are no direct benefits to participating in this study.

What are the alternatives to being in this study?

As an alternative to participating in this study, you can opt not to participate or choose an alternate form of communication such as email or phone.

How will my information be kept confidential?

We will take measures to protect the security of all your personal information, but we cannot guarantee confidentiality of all study data. You will not be asked to provide any personal information or information that could link you with your responses.

Information contained in your study records is used by study staff. The Portland State University Institutional Review Board (IRB) that oversees human subject research and/or other entities may be permitted to access your records, and there may be times when we are required by law to share your information. It is the investigator's legal obligation to report child abuse, child neglect, elder abuse, harm to self or others or any life-threatening situation to the appropriate authorities, and; therefore, your confidentiality will not be maintained.

Your name will not be used in any published reports about this study. Will I be paid for taking part in this study?

No

Can I stop being in the study once I begin?

Your participation in this study is completely voluntary. You have the right to choose not to participate or to withdraw your participation at any point in this study without penalty or loss of benefits to which you are otherwise entitled.

Whom can I call with questions or complaints about this study?

If you have any questions, concerns or complaints at any time about the research study, Jacob Suher, or his associates will be glad to answer them at 503-725-9875. If you need to contact someone after business hours or on weekends, please call 503-577-8974 and ask for Jacob Suher or call 970-376-3583 and ask for Ethan Cotton.

Whom can I call with questions about my rights as a research participant?

If you have questions regarding your rights as a research participant, you may call the PSU Office for Research Integrity at (503) 725-2227 or 1(877) 480-4400. The ORI is the office that supports the PSU Institutional Review Board (IRB). The IRB is a group of people from PSU and the community who provide independent oversight of safety and ethical issues related to research involving human participants. For more information, you may also access the IRB website at https://sites.google.com/a/pdx.edu/research/integrity. 


\section{CONSENT}

You are making a decision whether to participate in this study. By completing the interview you are agreeing to participate in this study.

\section{$\underline{\text { PSU Survey }}$}

\section{Shoe Drawing Graphic}

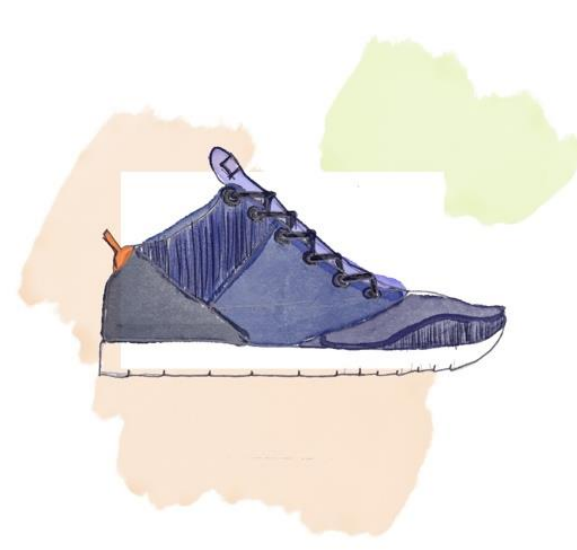

\section{Jacket Drawing Graphic}

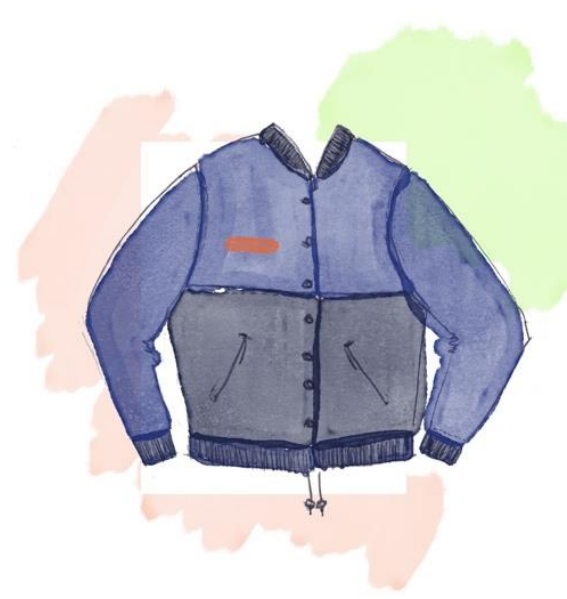

Shoe B Graphic

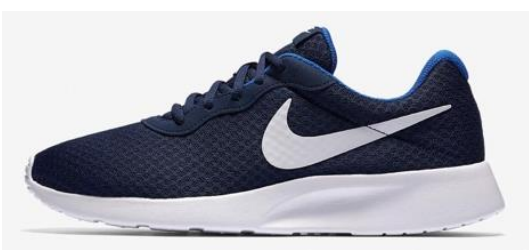

Jacket B Graphic 


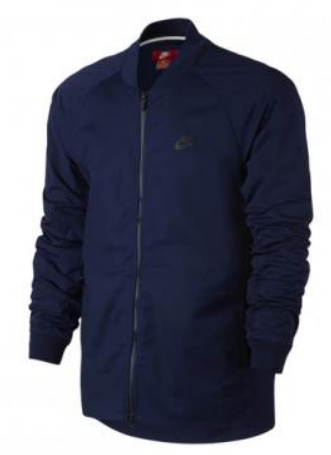

\section{Innovations Tested:}

- Material 1 (M1): Increase use of environmentally friendly materials

- Material 2 (M2): Increase use of durable and long-lasting materials

- Supply Chain 1 (SC1): Reduced use of resources to manufacture, package, and deliver the product

- Supply Chain 2 (SC2): Increased use of environmentally friendly practices to manufacture, package, and deliver the product

- Demand 1 (D1): Ethical practices throughout all materials and production practices

Drawing $\mathrm{n}=19$

Image $(B) n=84$

Please read the following information and answer the question below.

This a top selling product in the everyday athletic category. It offers a streamlined construction and comfortable midsole that doubles as an outsole.

Which option of the above product would you be more likely to purchase? Choose one of the options below.

\begin{tabular}{|l|l|l|l|}
\hline \multirow{3}{*}{$\begin{array}{l}\text { Innovation } \\
\text { vs. }\end{array}$} & Material 1 & vs. & Material 0 \\
\cline { 2 - 4 } Innovation & Material 2 & vs. & Material 0 \\
\cline { 2 - 4 } & Supply Chain 1 & vs. & Supply Chain 0 \\
\cline { 2 - 4 } & Supply Chain 2 & vs. & Supply Chain 0 \\
\cline { 2 - 4 } & Demand 1 & vs. & Demand 0 \\
\hline \multirow{3}{*}{$\begin{array}{l}\text { Innovation } \\
\text { Innovation }\end{array}$} & Material 1 & vs. & Material 2 \\
\cline { 2 - 4 } & Supply Chain 1 & vs. & Supply Chain 2 \\
\cline { 2 - 4 } & Material 1 & vs. & Supply Chain 1 \\
\cline { 2 - 4 } & Material 1 & vs. & Supply Chain 2 \\
\cline { 2 - 4 } & Material 2 & vs. & Supply Chain 1 \\
\cline { 2 - 4 } & Material 2 & vs. & Supply Chain 2 \\
\cline { 2 - 4 } & Material 1 & vs. & Demand 1 \\
\cline { 2 - 4 } & Material 2 & vs. & Demand 1 \\
\cline { 2 - 4 } & Supply Chain 2 & vs. & Demand 1 \\
\hline
\end{tabular}




\begin{tabular}{|l|l|l|l|}
\hline & Supply Chain 2 & vs. & Demand 1 \\
\hline
\end{tabular}

"Option without changes to materials and production practices" $=0$ option

On the sliding scales below, please indicate your willingness to pay for a product with each type of innovation.

Indicate your estimate as the percentage of the total price of a product where a positive $(+)$ value is the percent increase in cost and a negative (-) value is the percent decrease in cost. For example, zero (0\%) indicates you believe the cost of the product to the company is the same without the innovation.

Every question asked on a sliding scale:

$\begin{array}{llllllllll}-100 & -80 & -40 & -20 & 0 & 20 & 40 & 60 & 80 & 100\end{array}$

On the sliding scales below, please indicate your cost for a company to create a product with each type of innovation.

Indicate your estimate as the percentage of the total price of a product where a positive $(+)$ value is the percent increase in cost and a negative (-) value is the percent decrease in cost. For example, zero (0\%) indicates you believe the cost of the product to the company is the same without the innovation.

Every question asked on a sliding scale:

$\begin{array}{llllllllll}-100 & -80 & -40 & -20 & 0 & 20 & 40 & 60 & 80 & 100\end{array}$

\section{Product Usage}

How likely would you be to actually purchase the shoes shown below?

(shoe graphic)

Not at all Very

Likely Likely

$\begin{array}{lllllll}1 & 2 & 3 & 4 & 5 & 6 & 7\end{array}$

How likely would you be to actually purchase the jacket shown below?

(jacket graphic)

Not at all

Likely

$\begin{array}{lllllll}1 & 2 & 3 & 4 & 5 & 6 & 7\end{array}$

Very

Likely

If you were to purchase the shoes in this survey, what would be your primary use of the product?

-Athletic

-Fashion

-Everyday

-Other:

If you were to purchase jacket in this survey, what would be your primary use of the product? -Athletic 
-Fashion

-Everyday

-Other:

Usage

About how many times in the last two years have you purchased an athletic or outdoor apparel product of any type?

Zero (0)

One (1)

Two to four (2-4)

Five to ten (5-10)

Ten or more $(10+)$

I don't know

Demographics:

Please enter you zip code

(open response)

Overall, do you consider yourself an environmentally conscious person?

-Yes

-No

-I don't know

Do you consider yourself athletic/outdoorsy?

-Yes

-No

-I don't know

Do you do anything to actively reduce your environmental impact?

-Yes

-No

-I don't know

Do you know what recycling is?

-Yes

-No

-I don't know

\section{National Survey Design}

Utilize drawings from survey 2.

Please read the following information and answer the question below.

This a top selling product in the everyday athletic category. It offers a streamlined construction and comfortable midsole that doubles as an outsole.

Which option of the above product would you be more likely to purchase? Choose one of the options below. 


\section{Test 1: Ethics vs Environmental Friendliness}

1-4 with Shoe Graphic and description

1-4 with Jacket Graphic and description

1.

-Option without changes to materials and production practices

-Option with increased use of ethical social practices throughout all materials and production processes

2.

-Option without changes to materials and production practices

-Option with increased use of ethical social practices and decreased use of sustainable environmental practices throughout all materials and production processes

3.

-Option with increased use of sustainable environmental practices throughout all materials and production processes

-Option with increased use of ethical social practices throughout all materials and production processes

4.

-Option with increased use of sustainable environmental practices throughout all materials and production processes

-Option with increased use of ethical social practices and decreased use of sustainable environmental practices throughout all materials and production processes

\section{Test 2: Materials- Sustainability vs. Durability}

1-4 with Shoe Graphic and description

1-4 with Jacket Graphic and description

Please read the following information and answer the question below.

This a top selling product in the everyday athletic category. It offers a streamlined construction and comfortable midsole that doubles as an outsole.

Which option of the above product would you be more likely to purchase? Choose one of the options below.

$\underline{\text { Shoe }}$

1.

-Option with increased use of environmentally friendly materials -Option with use of durable and long-lasting materials

2.

-Option with increased use of environmentally friendly materials

-Option with use of durable and long lasting materials that are less environmentally friendly

3.

-Option with decreased waste of product materials

-Option with use of durable and long lasting materials

4.

-Option with decreased waste of product materials

-Option with use of durable and long-lasting materials that increase waste of product materials 


\section{Test 3: Performance/Lifestyle-Usage Moderation}

1-4 with Shoe Graphic and description

1-4 with Jacket Graphic and description

1.

- Performance option with increased use of environmentally friendly materials

- Performance option with increased use of environmentally friendly packaging and delivery of product

2.

-Performance option with increased use of environmentally friendly materials

- Lifestyle option with increased use of environmentally friendly packaging and delivery of product

3.

Lifestyle option with increased use of environmentally friendly materials

Performance option with increased use of environmentally friendly packaging and delivery of product

$\underline{4 .}$

Lifestyle option with increased use of environmentally friendly materials Lifestyle option with increased use of environmentally friendly packaging and delivery of product

Test 4: Impact Score: Materials vs Supply Chain

1-4 with Shoe Graphic and description

1-4 with Jacket Graphic and description

1.

-Option with environmentally friendly materials rating of 76 out of 100, where 100 indicates most environmentally friendly practices

-Option with environmentally friendly supply chain rating of 76 out of 100, where 100 indicates most environmentally friendly practices

2.

-Option with environmentally friendly materials rating of 24 out of 100 , where 100 indicates most environmentally friendly practices -Option with environmentally friendly supply chain rating of 76 out of 100, where 100 indicates most environmentally friendly practices 3.

-Option with environmentally friendly materials rating of 76 out of 100, where 100 indicates most environmentally friendly practices -Option with environmentally friendly supply chain rating of 24 out of 100 , where 100 indicates most environmentally friendly practices 4.

-Option with environmentally friendly materials rating of 24 out of 100, where 100 indicates most environmentally friendly practices -Option with environmentally friendly supply chain rating of 24 out of 100 , where 100 indicates most environmentally friendly practices

Test 5: Supply Chain vs Material-Distance Theory

1-4 with Shoe Graphic and description 
1-4 with Jacket Graphic and description

1.

-Option with use of materials sourced close to your location -Option with use of manufacturing close to your location 2.

-Option with use of materials sourced close to your location -Option with use of manufacturing far from your location 3.

-Option with use of materials sourced far from your location -Option with use of manufacturing close to your location 4.

-Option with use of materials sourced far from your location -Option with use of manufacturing far from your location 1.

-Option with use of materials sourced close to your location -Option with use of manufacturing close to your location 2. -Option with use of materials sourced close to your location -Option with use of manufacturing far from your location 3.

-Option with use of materials sourced far from your location -Option with use of manufacturing close to your location 4.

-Option with use of materials sourced far from your location -Option with use of manufacturing far from your location use of manufacturing far from your location

\section{Attribute Importance}

On a scale of 1-7, please rate the following attributes in terms of your perception of their importance when purchasing an athletic or outdoor apparel product (e.g., shoes or outerwear).

Remember, you are rating the importance of the attributes to you when purchasing an athletic or outdoor apparel product.

Randomized.

Scale:

Not Somewhat Very Important 12 Important

345

$5 \quad 6 \quad 7$

Increased the use of environmentally friendly materials Increased use of durable and long-lasting materials Reduced use of resources to manufacture, package and deliver the product Increased use of environmentally friendly practices to manufacture, package, and deliver the product 


\section{Impact Rating}

Remember, you are rating the impact of the attributes to you when purchasing an athletic or outdoor apparel product.

Randomized.

Scale:

Not

Important

12

\section{Somewhat} Important

Increased the use of environmentally friendly materials

Increased use of durable and long-lasting materials

Reduced use of resources to manufacture, package and deliver the product

Increased use of environmentally friendly practices to manufacture, package, and deliver the product

Ethical practices throughout all materials and product processes

\section{On the sliding scales below, please indicate your willingness to pay for a product with the innovations listed below.}

Indicate your willingness to pay as the percentage of the total price where a positive (+) value is the percent increase in price and a negative (-) value is the percent decrease in price. For example, zero $(0 \%)$ indicates you would pay the regular price for the product.

Every question asked on a sliding scale:
$-100-8$
$-40$
$-20$
$0 \quad 20$
40
$60 \quad 80$
100

Increased the use of environmentally friendly materials

Increased use of durable and long-lasting materials

Reduced use of resources to manufacture, package and deliver the product

Increased use of environmentally friendly practices to manufacture, package, and deliver the

Product

Ethical practices throughout all materials and product processes

\section{On the sliding scales below, please indicate your cost for a company to create a product with each type of innovation.}

Indicate your estimate as the percentage of the total price of a product where a positive (+) value is the percent increase in cost and a negative (-) value is the percent decrease in cost. For example, zero $(0 \%)$ indicates you believe the cost of the product to the company is the same without the innovation.

Every question asked on a sliding scale:

$\begin{array}{llllllllll}-100 & -80 & -40 & -20 & 0 & 20 & 40 & 60 & 80 & 100\end{array}$

- Increased the use of environmentally friendly materials

- Increased use of durable and long-lasting materials

- Reduced use of resources to manufacture, package and deliver the product

- Increased use of environmentally friendly practices to manufacture, package, and deliver the product 
- Ethical practices throughout all materials and product processes

Product Usage

How likely would you be to actually purchase the shoes shown below?

(shoe graphic)

Not at all Very

Likely Likely

$\begin{array}{lllllll}1 & 2 & 3 & 4 & 5 & 6 & 7\end{array}$

How likely would you be to actually purchase the jacket shown below?

(jacket graphic)

Not at all

Very

Likely

$\begin{array}{lllllll}1 & 2 & 3 & 4 & 5 & 6 & 7\end{array}$

If you were to purchase the shoes shown below, what would be your primary use of the product? (shoe graphic)

Athletic

Fashion

Everyday

Other:

If you were to purchase the jacket shown below, what would be your primary use of the product?

(Jacket graphic)

Athletic

Fashion

Everyday

Other:

We now would like you to think of real companies in the Athletic and Outdoor Industry. Remember that there are no right or wrong answers and your responses are completely anonymous.

To the best of your knowledge (no research necessary), please list the top three (3) Athletic and Outdoor companies with regard to efforts towards environmental sustainability.

\#1 Company

\#2 Company

\#3 Company

Please briefly describe your list of the top three (3) Athletic and Outdoor companies with regard to efforts towards environmental sustainability using the space below. E.g., How did you make this decision? Any specific comments about the companies?

Open Response:

About how many times in the last two years have you purchased an athletic or outdoor apparel product of any type?

Zero (0) 
One (1)

Two to four (2-4)

Five to ten (5-10)

Ten or more $(10+)$

I don't know

Please use the scale below to estimate how many times in the last two years have you purchased an athletic or outdoor apparel product of any type? (same as last question) \# of athletic or outdoor purchases

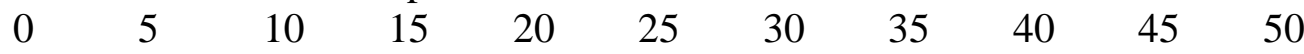

Listed below are statements about the relationship between humans and the environment. For each one, please indicate whether you STRONGLY AGREE, MILDLY AGREE, are UNSURE, MILDLY DISAGREE or STRONGLY DISAGREE with it.

We are approaching the limit of the number of people the earth can support Humans have the right to modify the natural environment to suit their needs When humans interfere with nature it often produces disastrous consequences Human ingenuity will insure that we do NOT make the earth unlivable Humans are severely abusing the environment The earth has plenty of natural resources if we just learn how to develop them Plants and animals have as much right as humans to exist

The balance of nature is strong enough to cope with the impacts of modern industrial nations Despite our special abilities humans are still subject to the laws of nature The so-called "ecological crisis" facing humankind has been greatly exaggerated The earth is like a spaceship with very limited room and resources Humans were meant to rule over the rest of nature The balance of nature is very delicate and easily upset Humans will eventually learn enough about how nature works to be able to control it If things continue on their present course, we will soon experience a major ecological catastrophe Humans will select strongly disagree for this item to pass attention check

Please select your age range:

18-24

25-34

$45-54$

55-64

$65+$

What gender do you identify with?

-Female

-Male

-Non-binary/third gender

-Prefer to self-describe: open response 
-Prefer not to say

Please select your state

(dropdown list)

Please enter you zip code

(open response)

Overall, do you consider yourself an environmentally conscious person?

-Yes

-No

-I don't know

Do you consider yourself athletic/outdoorsy?

-Yes

-No

-I don't know

Do you do anything to actively reduce your environmental impact?

-Yes

-No

-I don't know

Do you know what recycling is?

-Yes

-No

-I don't know

\section{REFERENCES}

See literature review in Table 1

Bolte, Matt. "Nike Global Sportswear Merchandising Manager” Personal interview. 31 May. 2017.

Del Pilar, Samuel. “Adidas Product Marketing Manager.” Personal interview. 26 May. 2017. Gilbride, Adrianne. Purpose beyond Profit: Sustainability in the Outdoor Industry. Diss. Blekinge Institute of Technology, 2014.

Egbue, Ona, and Suzanna Long. "Barriers to Widespread Adoption of Electric Vehicles: An Analysis of Consumer Attitudes and Perceptions.” Energy Policy 48 (2012): 717-29. 
Web. 10 June 2017.

Einwiller, Sabine A, et al. "Under What Conditions Do the News Media Influence Corporate Reputation? The Roles of Media Dependency and Need for Orientation." Corporate Reputation Review, vol. 12, no. 4, Winter2010, pp. 299-315.

Hasford, Jonathan, and Adam Farmer. "Responsible You, Despicable Me: Contrasting Competitor Inferences from Socially Responsible Behavior.” Journal of Business Research 69.3 (2016): 1234-241. Web. 8 June 2017.

Joshi, Yatish, and Zillur Rahman. "Factors Affecting Green Purchase Behaviour and Future Research Directions.” International Strategic Management Review 3.1-2 (2015): 128- 143. ScienceDirect. Web.

Ki, Chung-Wha, and Youn-Kyung Kim. "Sustainable Versus Conspicuous Luxury Fashion Purchase: Applying Self-Determination Theory." Family and Consumer Sciences Research Journal 44.3 (2016): 309-323. Wiley Online Library. Web.

Klaiman, Kimberly, David L. Ortega, and Cloé Garnache. "Perceived Barriers to Food Packaging Recycling: Evidence from a Choice Experiment of US Consumers.” Food Control 73 (2017): 291-99. Web.

Luchs, Michael G., Rebecca Walker Naylor, Julie R. Irwin, and Rajagopal Raghunathan. "The Sustainability Liability: Potential Negative Effects of Ethicality on Product Preference.” Journal of Marketing 74.5 (2010): 18-31. Web.

Lundblad, Louise, and Iain A. Davies. "The Values and Motivations behind Sustainable Fashion Consumption.” Journal of Consumer Behaviour 15.2 (2016): 149-162. Wiley Online Library. Web.

Sheth, Jagdish N., Nirmal K. Sethia, and Shanthi Srinivas. "Mindful Consumption: A 
Customer Centric Approach to Sustainability." Journal of the Academy of Marketing Science 39.1 (2011): 21-39. Web.

“Geng, Duanyang, Junjun Liu, and Qinghua Zhu. "Motivating Sustainable Consumption among Chinese Adolescents: An Empirical Examination.” Journal of Cleaner Production 141 (2017): 315-322. ScienceDirect. Web.

Lin, Ying-Ching, and Chiu-chi Angela Chang. "Double standard: The role of environmental consciousness in green product usage." Journal of Marketing 76.5 (2012): 125-134.

Moore, Hannah. "Nike Sustainable Product Analyst.” Personal interview. 7 Apr. 2017.

Peloza, John, and Jingzhi Shang. "How Can Corporate Social Responsibility Activities Create Value for Stakeholders? A Systematic Review." Journal of the Academy of Marketing Science 39.1 (2010): 117-35. Web. 2 June 2017.

\section{ADDITIONAL SOURCES}

“Adidas Will Open Atlanta-Based Facility to Make Shoes in America." Adidas Will Open Atlanta-Based Facility to Make Shoes in America. Adidas Group, 10 Aug. 2016. Web. 11 June 2017.

“BCI Quarterly Report.” BetterCotton.org, Better Cotton Initiative, 1 Jan. 2018.

"Eco-Innovation the Key to Europe's Future Competitiveness." European Commission Environment Publications, European Union, 6 Aug. 2016.

"Green Generation: Millennials Say Sustainability Is a Shopping Priority." What People Watch,

Listen To and Buy. The Nielsen Company (US), LLC, 5 Nov. 2015. Web. 05 June 2017.

New, Steve. “The Transparent Supply Chain.” Harvard Business Review, Harvard Business

School Publishing, 7 Sept. 2017, hbr.org/2010/10/the-transparent-supply-chain

"New York Times | International Luxury Conference | 2016 | Day 1 | Strategic Sustainability. 
Dir. Vanessa Friedman. Perf. Cyrill Gutsch, Eric Liedtke, Brunello Cucinelli, Michael Kowalski. YouTube. New York Times, 6 Apr. 2016. Web. 23 May 2017.

“Nike Innovation 2016.” Nike News, Nike Inc., 2016, news.nike.com/news/nike-innovation 2016.

Outdoor Industry Association. "OIA ConsumerVue Executive Summary.” Outdoor Industry Association. 12 May. 2015. Web. 3 June. 2017.

“OutDry Extreme ECO Landing." Columbia. Columbia Sportswear Company, n.d. Web. 12 June 2017.

“Retail Sustainability In An Omnichannel World.” Retail TouchPoints. UXC Eclipse, 2016. Web. 05 Apr. 2017.

“Restricted Substance List (RSL).” ApparelStats and ShoeStats at-a-Glance, 1 Feb. 2018, www.aafaglobal.org/AAFA/Solutions_Pages/Restricted_Substance_List. 